\title{
Article \\ Challenges of Formation of Thin-Film Solid Electrolyte Layers on Non-Conductive Substrates by Electrophoretic Deposition
}

\author{
Elena Kalinina ${ }^{1,2, *} \mathbb{D}$, Elena Pikalova ${ }^{3,4} \mathbb{D}$, Larisa Ermakova ${ }^{5}$ and Nina Bogdanovich ${ }^{3}$ \\ 1 Laboratory of Complex Electrophysic Investigations, Institute of Electrophysics, Ural Branch of the Russian \\ Academy of Sciences, 620016 Yekaterinburg, Russia \\ 2 Department of Physical and Inorganic Chemistry, Institute of Natural Sciences and Mathematics, \\ Ural Federal University, 620002 Yekaterinburg, Russia \\ 3 Laboratory of Solid Oxide Fuel Cells, Institute of High Temperature Electrochemistry, Ural Branch of the \\ Russian Academy of Sciences, 620137 Yekaterinburg, Russia; e.pikalova@list.ru (E.P.); \\ bogdanovich@ihte.uran.ru (N.B.) \\ 4 Department of Environmental Economics, Graduate School of Economics and Management, \\ Ural Federal University, 620002 Yekaterinburg, Russia \\ 5 Laboratory of Chemistry of Compounds of Rare-earth Elements, Institute of Solid State Chemistry, \\ Ural Branch of the Russian Academy of Sciences, 620990 Yekaterinburg, Russia; larisaer@ihim.uran.ru \\ * Correspondence: jelen456@yandex.ru; Tel.: +7-343-267-87-82
}

Citation: Kalinina, E.; Pikalova, E.; Ermakova, L.; Bogdanovich, N. Challenges of Formation of Thin-Film Solid Electrolyte Layers on Non-Conductive Substrates by Electrophoretic Deposition. Coatings 2021, 11, 805. https://doi.org/ 10.3390/coatings11070805

Academic Editor: Alberto Palmero

Received: 15 June 2021

Accepted: 28 June 2021

Published: 2 July 2021

Publisher's Note: MDPI stays neutral with regard to jurisdictional claims in published maps and institutional affiliations.

Copyright: (c) 2021 by the authors. Licensee MDPI, Basel, Switzerland. This article is an open access article distributed under the terms and conditions of the Creative Commons Attribution (CC BY) license (https:// creativecommons.org/licenses/by/ $4.0 /)$.
Abstract: In this work, the challenges associated with the formation of single and bilayer coatings based on $\mathrm{Ce}_{0.8} \mathrm{Sm}_{0.2} \mathrm{O}_{1.9}$ (SDC) and $\mathrm{CuO}$ modified $\mathrm{BaCe}_{0.5} \mathrm{Zr}_{0.3} \mathrm{Y}_{0.1} \mathrm{Yb}_{0.1} \mathrm{O}_{3-\delta}$ (BCZYYbO-CuO) solid state electrolytes on porous non-conducting NiO-SDC anode substrates by the method of electrophoretic deposition (EPD) are considered. Various approaches that had been selected after analysis of the literature data in order to carry out the EPD, are tested: direct deposition on a porous non-conductive anode substrate and multiple options for creating the conductivity of the anode substrate under EPD conditions such as the reduction of the NiO-SDC substrate and the creation of a surface conducting sublayer via synthesizing a polypyrrole (PPy) film. New effective method was proposed based on the deposition of a platinum layer on the front side of the substrate. It was ascertained that, during the direct EPD on the porous NiO-SDC substrate, the formation of a continuous coating did not occur, which may be due to insufficient porosity of the substrate used. It was shown that the use of reduced substrates leads to cracking and, in some cases, to the destruction of the entire SDC/NiO-SDC structure. The dependence of the electrolyte film sinterability on the substrate shrinkage was studied. In contrast to the literature data, the use of the substrates with a reduced pre-sintering temperature had no pronounced effect on the densification of the SDC electrolyte film. It was revealed that complete sintering of the SDC electrolyte layer with the formation of a developed grain structure is possible at a temperature of $1550{ }^{\circ} \mathrm{C}$.

Keywords: electrophoretic deposition; solid oxide fuel cell; thin-film electrolyte; anode-supported cell; doped ceria; bilayer coating; deposition kinetics; sintering kinetics; conducting layer; densification

\section{Introduction}

Solid oxide fuel cells (SOFCs) are environment friendly electrochemical devices that convert chemical energy of continuously supplied hydrocarbon fuel into electricity with high efficiency (approximately 70\%) [1,2]. The demand on decreasing SOFC operating temperatures has facilitated the development of the cell design with a thin-film solid state electrolyte on supporting substrates-anode, cathode, porous electrolyte and metallic carriers [3-5]. The recently developed technologies were extended to the deposition of two and multilayer electrolyte membranes prospective for the enhancement of the cell performance and durability [6-10]. To deposit thin dense electrolyte films various methods have been applied such as chemical and physical vapor deposition and plasma 
spaying [11,12], atomic layer deposition [13], pulsed laser deposition and magnetron sputtering [14-16] and some ceramic and colloidal techniques [17-19].

Among the technologies under intensive development, the method of electrophoretic deposition (EPD) is an industrially relevant process which is technologically simple, easily adaptable to the substrate shape and electrolyte content and less cost and time-consuming than many other colloidal and gas-phase processes [20]. Compared to the dipped or sprayed coatings, electrophoretically deposited coatings demonstrate superior adherence and high green density and thus ensure fabrication of uniform and gas-tight electrolyte films [21]. In comparison with casting methods, the EPD rate is less influenced by particle size and remains relatively fast when the coatings based on electrolyte nanopowders are fabricated [22,23]. As compared with tape casting, the EPD is also suitable for the formation of multilayered systems with easily controlled thickness of layers [24].

Since sufficient substrate conductivity is one of the main requirements for the successful EPD implementation, in this regard, for the deposition of electrolyte films, it would be preferable to use cathode substrates that possess a high conductivity level at room temperature. However, cathode polarization resistance is well known to be a key factor influencing the power density of thin-film electrolyte SOFCs, especially at reduced operating temperatures [25] due to complicated multistage process of oxygen reduction. Thus, thick cathode substrate would greatly contribute to reduction of the electrode kinetics and deterioration of the cell performance [26]. In this sense, anode-supported constructions are preferable to use. However, NiO-cermet anodes, traditionally used in SOFCs, are non-conductive under the EPD conditions. In Table 1 we summarized different approaches applied to deposition of thin electrolyte films on anode substrates.

Table 1. Methods of the substrate preparation, EPD modes and sintering conditions of the electrolyte films fabricated on non-conductive anode substrates.

\begin{tabular}{|c|c|c|c|c|}
\hline Anode//Electrolyte & Substrate Pre-Treatment & EPD Mode & Sintering & Ref. \\
\hline NiO-YSZ/ /YSZ (3 $\mu \mathrm{m})$ & $\begin{array}{c}\text { Pre-sintering at } 900{ }^{\circ} \mathrm{C}, 4 \mathrm{~h} \text {, applying a } \\
\text { conducting steel plate on the reverse side of } \\
\text { the substrate }\end{array}$ & $40 \mathrm{~V}, 10 \mathrm{~min}$ & $1200^{\circ} \mathrm{C}, 2 \mathrm{~h}$ & [23] \\
\hline NiO-YSZ//YSZ (10 $\mu \mathrm{m})$ & $\begin{array}{l}\text { Pre-sintering at } 1000{ }^{\circ} \mathrm{C}, 2 \mathrm{~h} \text {, using a carbon } \\
\text { type on the reverse side of the substrate }\end{array}$ & $50 \mathrm{~V}, 180 \mathrm{~s}$ & $1450^{\circ} \mathrm{C}, 5 \mathrm{~h}$ & [27] \\
\hline NiO-YSZ//YSZ (20 ㅆm) & $\begin{array}{l}\text { Pre-sintering at } 700-1100{ }^{\circ} \mathrm{C}, 1 \mathrm{~h} \text {, reduction } \\
\text { in } 10 \% \mathrm{H}_{2}-90 \% \mathrm{Ar}\end{array}$ & $5-15 \mathrm{~V}, 180 \mathrm{~s}$ & $1400^{\circ} \mathrm{C}, 1 \mathrm{~h}$ & [28] \\
\hline NiO-YSZ/ /YSZ (5 ㅆm) & $\begin{array}{l}\text { Pre-sintering at } 900-1200{ }^{\circ} \mathrm{C}, 2 \mathrm{~h} \text {, graphite } \\
\text { layer }(0.61-1 \mu \mathrm{m}) \text { deposited on the reverse } \\
\text { side (method } 1) \text { or front side (method } 2) \text { of } \\
\text { the substrate }\end{array}$ & $50-400 \mathrm{~V}$ & $1350^{\circ} \mathrm{C}, 2 \mathrm{~h}$ & [29] \\
\hline $\begin{array}{c}\mathrm{NiO}-\mathrm{YSZ} / / \mathrm{YSZ}(4 \mu \mathrm{m}) / \mathrm{SDC} \\
(1 \mu \mathrm{m})\end{array}$ & $\begin{array}{l}\text { Pre-sintering at } 900{ }^{\circ} \mathrm{C}, 2 \mathrm{~h} \text {, graphite layer } \\
(1 \mu \mathrm{m}) \text { on the reverse side of the substrate }\end{array}$ & $600 \mathrm{~V}, 60 \mathrm{~s}$ & $\begin{array}{l}1400{ }^{\circ} \mathrm{C}, 2 \mathrm{~h} \text { in } \\
\text { air }\end{array}$ & {$[30]$} \\
\hline NiO-YSZ/ /YSZ ( 3 $\mu \mathrm{m})$ & $\begin{array}{l}\text { PIM }^{3} \text { anode substrates without } \\
\text { pre-sintering }\end{array}$ & $30 \mathrm{~V}, 120 \mathrm{~s}$ & $1250^{\circ} \mathrm{C}, 2 \mathrm{~h}$ & [31] \\
\hline $\mathrm{LDC}^{5} / / \mathrm{LGSM}^{6}(30 \mu \mathrm{m})$ & Tape-cast LDC + carbon & - & $1490^{\circ} \mathrm{C}$ & [32] \\
\hline $\begin{array}{c}\mathrm{NiO}-\mathrm{Zr}(\mathrm{Sc}) \mathrm{O}_{2} / / \mathrm{Zr}(\mathrm{Sc}) \mathrm{O}_{2} \\
(5-20 \mu \mathrm{m})\end{array}$ & $\begin{array}{l}\mathrm{NiO}-\mathrm{Zr}(\mathrm{Sc}) \mathrm{O}_{2}+10 \mathrm{wt} . \% \mathrm{PMMA}^{7} \\
\text { pre-sintered at } 900{ }^{\circ} \mathrm{C}, 1 \mathrm{~h} \text {, reduced at } \\
\qquad 600^{\circ} \mathrm{C} \text { for } 1 \mathrm{~h} \text { in } \mathrm{H}_{2} / \mathrm{Ar}\end{array}$ & $10-50 \mathrm{~V}, 5-50 \mathrm{~min}$ & $1300^{\circ} \mathrm{C}, 5 \mathrm{~h}$ & [33] \\
\hline $\mathrm{NiO}-\mathrm{YSZ} / \mathrm{AFL}^{8} / / \mathrm{YSZ}(5 \mu \mathrm{m})$ & $\begin{array}{c}\text { Pre-sintering at } 1100^{\circ} \mathrm{C}, 2 \mathrm{~h} \text {, covering with } \\
\text { polypyrrole (surface synthesis) }\end{array}$ & $15-40 \mathrm{~V}, 1-4 \mathrm{~min}$ & $1400{ }^{\circ} \mathrm{C}, 6 \mathrm{~h}$ & [34] \\
\hline $\begin{array}{l}\mathrm{NiO}-Y S Z / / G D C \\
9 / \mathrm{LSGM} / \mathrm{GDC}\end{array}$ & $\begin{array}{c}\text { Pre-sintering at } 900{ }^{\circ} \mathrm{C}, 2 \mathrm{~h} \text {, covering with } \\
\text { polypyrrole } \\
\text { (surface synthesis) }\end{array}$ & $50 \mathrm{~V}$ & $1400^{\circ} \mathrm{C}, 6 \mathrm{~h}$ & [35] \\
\hline
\end{tabular}


Table 1. Cont

\begin{tabular}{|c|c|c|c|c|}
\hline Anode//Electrolyte & Substrate Pre-Treatment & EPD Mode & Sintering & Ref. \\
\hline $\begin{array}{l}\mathrm{NiO}-\mathrm{BCY} \mathrm{B}^{10} / / \mathrm{BCY} \\
\quad(6.2-13.4 \mu \mathrm{m})\end{array}$ & $\begin{array}{c}\mathrm{NiO}-\mathrm{BCY}+\text { graphite }(25 \text { wt. } \%)+\text { PVA }^{12} \\
(5 \text { wt. } \%)\end{array}$ & $40 \mathrm{~V}, 1-5 \mathrm{~min}$ & $\begin{array}{l}1000^{\circ} \mathrm{C} / 1500 \\
{ }^{\circ} \mathrm{C}, 2 \mathrm{~h}\end{array}$ & [36] \\
\hline NiO-YSZ/ /YSZ (7.2 ㅆm) & $\begin{array}{c}\mathrm{NiO}-\text { YSZ-starch }(5: 5: 1) \text {, pre-sintering at } \\
900{ }^{\circ} \mathrm{C}, 2 \mathrm{~h} \text {, deposition of graphite layer on } \\
\text { the substrate front side }\end{array}$ & $75 \mathrm{~V}, 2 \mathrm{~min}$ & $1400^{\circ} \mathrm{C}, 2 \mathrm{~h}$ & [37] \\
\hline NiO-YSZ/ /YSZ (7.2 ㅆm) & $\begin{array}{c}\text { NiO-YSZ }(5: 5)+\operatorname{starch}(15 \text { wt. } \%) \\
\text { pre-sintering at } 900{ }^{\circ} \mathrm{C}, 4 \mathrm{~h}+\mathrm{AFL}(\mathrm{EPD}) \\
\text { sintering at } 800^{\circ} \mathrm{C}, 2 \mathrm{~h}\end{array}$ & $30 \mathrm{~V}, 2 \mathrm{~min}$ & $1400{ }^{\circ} \mathrm{C}, 2 \mathrm{~h}$ & [38] \\
\hline NiO-YSZ/ /YSZ (7.2 ㅆm) & $\begin{array}{c}\mathrm{NiO}-\text { YSZ-starch }(5: 5: 2) \text {, pre-sintering at } \\
1000^{\circ} \mathrm{C}, 3 \mathrm{~h} \text {, graphite layer painted on the } \\
\text { substrate front side }\end{array}$ & $20 \mathrm{~V}, 2 \mathrm{~min}$ & $\begin{array}{l}1300-1600{ }^{\circ} \mathrm{C}, \\
4 \mathrm{~h}\end{array}$ & [39] \\
\hline $\begin{array}{l}\text { NiO-YSZ/ /YSZ (19 } \mu \mathrm{m}(1 \\
\text { method), } 34.6 \text { ( } 2 \text { method })\end{array}$ & $\begin{array}{l}\text { NiO-YSZ-starch (5:5:1), pre-sintering at } \\
900{ }^{\circ} \mathrm{C}, 3 \mathrm{~h} \text { (method 1), pre-sintering and a } \\
\text { graphite layer depsition on the substrate } \\
\text { front side (method 2) }\end{array}$ & $50 \mathrm{~V}, 3 \mathrm{~min}$ & $1350{ }^{\circ} \mathrm{C}, 4 \mathrm{~h}$ & [40] \\
\hline NiO-CSZ ${ }^{13} / /$ YSZ $(5 \mu \mathrm{m})$ & $\begin{array}{l}\text { NiO-CSZ-ethylene glycol }(10 \%) \\
\text { pre-sintering } 1450{ }^{\circ} \mathrm{C}, \mathrm{Pt} \text { coated }\end{array}$ & $5 \mathrm{~V}, 3 \mathrm{~min}$ & $\begin{array}{l}1350^{\circ} \mathrm{C}, 1 \mathrm{~h}, \\
5 \text { cycles }\end{array}$ & [41] \\
\hline NiO-YSZ/ /YSZ (17 $\mu \mathrm{m})$ & $\begin{array}{l}\mathrm{NiO}-\mathrm{YSZ} \text {-starch }(6: 4: 1) \text { pre-sintering at } 1200 \\
\text { and } 1350{ }^{\circ} \mathrm{C} \text {, reducing in } \mathrm{H}_{2} \text { at } 850^{\circ} \mathrm{C}, 5 \mathrm{~h}\end{array}$ & $\begin{array}{l}35 \mathrm{~V}, 1 \mathrm{~ms}, 6 \mathrm{~min} \\
\text { (pulsed) }\end{array}$ & $1350{ }^{\circ} \mathrm{C}, 4 \mathrm{~h}$ & [42] \\
\hline
\end{tabular}

In a number of studies, the EPD of single or bilayer electrolyte films was performed by electrophoretic filtration on the porous non-conducting substrates of $50-60 \%$ porosity. To establish conductive path through the porous structure, the opposite side of the substrates was covered with carbon [27-29] or platinum [41]. In these studies, the anode substrates were pre-sintered at the temperatures of $900-1200{ }^{\circ} \mathrm{C}$ and their shrinkage during cofiring with the electrolyte at higher temperatures facilitated densification of the electrolyte film. The lowest sintering temperatures for the yttria stabilized zirconia (YSZ) films of $1200-1250{ }^{\circ} \mathrm{C}$ were reached when using for their deposition the anode substrates with intrinsic microporosity fabricated by ceramic injection molding from the mixture of $\mathrm{NiO}$ YSZ and polymer binders (PEG and PVB resin) without any pre-sintering step [30] or when using for EPD nano-sized YSZ electrolyte material subjected special treatment to destroy agglomerates [23].

In another approach, electrolyte layers are deposited on highly conducting reduced anode substrates $[28,33,42]$. The main problem of this method is related to the selection of a proper layer's thickness ratio and sintering conditions which could maximally match the sintering behavior of the reduced substrate and electrolyte films.

The substrate conductivity can be enhanced by introducing a conducting powder into green anode substrates [32,37] or creating a conductive layer on the front size of the substrate by means of deposition of polypyrrole (PPy) [34,35], graphite [29,37,39], or silver [43]. Comparison of the effectiveness of the methods of electrophoretic filtration and using a conductive surface layer in EPD on non-conductive substrates was performed by Talebi et al. [40]. In the first method, the NiO-YSZ highly porous substrate ( $\sim 64 \%$ porosity) was placed in front of a stainless-steel electrode; in the second method, the substrate surface conductivity was facilitated by deposition of a thin graphite layer on the top of the substrate. It was shown that the deposition weight, thickness and quality of coatings formed on the graphite layer were significantly higher than those deposited directly on the non-conductive substrate. In the second case there were a lot of cracks on the film surface after sintering. In the study of Matsuda et al. [29], contrary, the direct deposition of the YSZ film on a non-conductive NiO-YSZ substrate ( $\sim 57 \%$ porosity) was found to be more 
preferable that that on a graphite layer. Comparative studies make it possible to find an optimal solution for a specific task of forming SOFCs with a certain set of materials used for functional layers.

Another important issue to achieve good quality of the electrolyte film using the EPD is the preparation of stable suspension. It is a challenging task especially when using submicron powders due to their strong agglomeration tendency. Therefore, the choice of appropriate solvent and dispersant, as well as special suspension treatment is crucial for the suspensions' stabilization.

The experimental part of this paper presents epy initial investigative steps for EPD of thin solid-state electrolyte films on non-conductive substrates undertaken by our group. We represent a full cycle of the necessary preparations and process implementation. Special attention is paid to the preparation of stable suspensions for EPD based on electrolytes of different dispersity, as well as an electrolyte with a sintering additive. To reduce particle aggregation in the suspensions, ultrasonic treatment is applied. Optimal deposition modes are established through the deposition on the model substrates. A comparative experimental analysis on the EPD process on non-conductive substrates is carried out using known approaches considered in the works of other scientific groups. The difficulties that arose when implementing the different methods are discussed. An alternative method for creating solid electrolyte films is proposed based of the surface modification of a non-conductive anode substrate by the deposition of a platinum sublayer on its front surface. The implementation of this approach makes it possible to carry out multiple deposition-sintering cycles while maintaining the conductivity of the substrate under EPD conditions.

\section{Materials and Methods}

\subsection{Synthesis and Characterization of the Electrolytes}

$\mathrm{Ce}_{0.8} \mathrm{Sm}_{0.2} \mathrm{O}_{1.9}$ (SDC) electrolyte powder was synthesized by a solution combustion synthesis (SCS) using a combined organic fuel-a mixture of glycine (gl) and citric acid (cit). The intensity of the combustion reaction was regulated by varying the gl:cit ratio to prevent the removal of the synthesis product from the reaction vessel. For the synthesis of SDC powder, the following initial reagents were used: $\mathrm{Ce}\left(\mathrm{NO}_{3}\right)_{3} \cdot 6 \mathrm{H}_{2} \mathrm{O}(99.9 \mathrm{wt} . \%)$, $\mathrm{Sm}\left(\mathrm{NO}_{3}\right)_{3} \cdot 6 \mathrm{H}_{2} \mathrm{O}(99.0 \mathrm{wt} . \%)$, glycine and citric acid. Cerium and samarium nitrate salts were dissolved in distilled water; the resulting solutions were mixed, and then the calculated amount of glycine and citric acid ( $1.4 \mathrm{~mol}$ of the combined fuel $\left(0.6_{\mathrm{gl}}: 0.8_{\mathrm{cit}}\right)$ per 1 mole of the mixed oxide) was added and stirred until complete dissolution. The reaction solution was heated until the formation of the xerogel and its subsequent combustion. The resulting powder was calcined in air at $900^{\circ} \mathrm{C}$ for $5 \mathrm{~h}$. The specific surface area of the SDC powder, determined by the brunauer, emmett and teller (BET) method, $\mathrm{S}_{\mathrm{BET}}$, was $12 \mathrm{~m}^{2} / \mathrm{g}$.

$\mathrm{BaCe}_{0.5} \mathrm{Zr}_{0.3} \mathrm{Y}_{0.1} \mathrm{Yb}_{0.1} \mathrm{O}_{3-\delta}(\mathrm{BCZYYbO})$ electrolyte powder was synthesized by a citrate-nitrate method using citric acid as a chelating agent and organic fuel in the pyrolysis of the reacting mixture. $\mathrm{BaCO}_{3}(99.0 \mathrm{wt} . \%), \mathrm{Y}_{2} \mathrm{O}_{3}$ (99.9 wt.\%), $\mathrm{Yb}_{2} \mathrm{O}_{3}$ (99.5 wt.\%), $\mathrm{Ce}\left(\mathrm{NO}_{3}\right)_{3} \cdot 6 \mathrm{H}_{2} \mathrm{O}\left(99.9\right.$ wt.\%), $\mathrm{Zr}(\mathrm{OH})_{2} \mathrm{CO}_{3}(98.4 \mathrm{wt} . \%)$ were used as starting reagents. To remove adsorbed moisture and gases, $\mathrm{BaCO}_{3}, \mathrm{Yb}_{2} \mathrm{O}_{3}$ and $\mathrm{Y}_{2} \mathrm{O}_{3}$ materials were preliminarily calcined for $10 \mathrm{~h}$ at a temperature of 600,1000 , and $1100^{\circ} \mathrm{C}$, respectively. The starting powders were dissolved in distilled water, and the resulting solutions were mixed and heated for 10-20 min. After that an ammonia solution (10 vol.\%) was added drop by drop until a slightly acidic medium was established $(\mathrm{pH}=6-7)$. Citric acid was added to the solution in an amount calculated to the yield product. Then the solution was evaporated. The obtained powder was annealed in air sequentially in several 5-h stages at 1050 and $1150{ }^{\circ} \mathrm{C}$ with intermediate grinding in ethanol. The final stage of synthesis was performed at a temperature of $1150{ }^{\circ} \mathrm{C}$ for $10 \mathrm{~h}$. The $\mathrm{BCZYYbO}$ specific surface area determined by the BET method was $1.3 \mathrm{~m}^{2} / \mathrm{g}$. To enhance sintering of the $\mathrm{BCZYYbO}$ coatings, $\mathrm{CuO}$ as a sintering additive in the amount of $5 \mathrm{wt}$.\% was introduced into the $\mathrm{BCZYYbO}$ electrolyte powder by adding an alcohol solution of $\mathrm{Cu}\left(\mathrm{NO}_{3}\right)_{2} \cdot 3 \mathrm{H}_{2} \mathrm{O}(99.0 \mathrm{wt} . \%)$. The mixture was stirred, dried, and decomposed at $400{ }^{\circ} \mathrm{C}$ for $1 \mathrm{~h}$. 
The X-ray diffraction (XRD) analysis of the obtained samples was carried out on a XRD7000 diffractometer (Shimadzu, Kyoto, Japan) in a $\mathrm{CuK} \alpha$ radiation and in an angle range of $2 \theta=20^{\circ}-80^{\circ}$. Data processing and phase identification were performed by comparing the XRD patterns obtained with those in the PDF-4 database (ICDD, Newtown, PA, USA, Release 2018). The specific surface area of the powders was determined by a BET volumetric method for low-temperature equilibrium sorption of nitrogen vapor from mixtures with helium using a TriStar 3000 vacuum sorption unit (Micromeritics, Norcross, Germany). Dilatometric measurements were carried out on the samples of materials compacted by a magnetic-pulse method, as described elsewhere [44], using a DIL 402 C dilatometer (NETZSCH, Selb, Germany) in the heating mode up to $1500{ }^{\circ} \mathrm{C}$ and under subsequent cooling at a constant rate of $5^{\circ} \mathrm{C} / \mathrm{min}$. The experiments were carried out in an air flow of $100 \mathrm{~mL} / \mathrm{min}$.

\subsection{Fabrication of the Anode Substrates and Their Characterization}

For the fabrication of anode substrates, the SDC electrolyte powder was calcined at $1100{ }^{\circ} \mathrm{C}$ for $5 \mathrm{~h}$ to decrease its specific surface area down to $1.2 \mathrm{~m}^{2} / \mathrm{g}$. NiO (98.4 wt.\%) and the SDC electrolyte powders were mixed in a ratio of 56/44 wt.\% with the addition of a polyvinyl butyral binder and compacted by uniaxial semi-dry pressing at a pressure of $16 \mathrm{MPa}$, and then sintered at a temperature of $1400{ }^{\circ} \mathrm{C}$ for $2 \mathrm{~h}$ in air (Nabertherm LHT-04/18 furnace, Lilienthal, Germany). Pre-sintered anode substrates were polished using a diamond grinding disc and then treated in an ultrasonic bath in isopropyl alcohol to clean the surface and annealed at $900{ }^{\circ} \mathrm{C}$ for $1 \mathrm{~h}$. The density of the anode substrates was determined by weighing and measuring the geometric dimensions and amounted approximately $72-74 \%$. The gas permeability of the anode substrates was measured on a specialized installation (IEP UB RAS, Yekaterinburg, Russia) by a decay method. This method is based on a Darcy's law [45]. The gas permeability coefficient was determined by a law of time-dependent pressure that is decreased due to gas permeation through the porous substrate. The average gas permeability coefficient measured for the anode substrates pre-sintered at $1400{ }^{\circ} \mathrm{C}$ (experiments with four samples) was $1.6 \times 10^{-3} \mu^{2}$.

To investigate the influence of the shrinkage of the anode substrate on the electrolyte film densification during co-sintering, some of the NiO-SDC anode substrates fabricated without/with a pore former (graphite, $13 \mathrm{~m}^{2} / \mathrm{g}$ taken in amount of $20 \mathrm{wt} . \%$ ) were sintered at $1200{ }^{\circ} \mathrm{C}, 2 \mathrm{~h}$. The density of the anode substrates sintered at decreased temperatures was in a range of $53-60 \%$ of the theoretical value. The conductive layer on the surface of the anode substrates was created by synthesizing a polypyrrole (PPy) film. PPy was synthesized by chemical polymerization $[35,46]$.

\subsection{Preparation of the Suspensions Based on the Electrolyte Materials and Their Characterization}

For the preparation of suspensions based on the electrolyte materials, a mixed dispersion medium of isopropanol/acetylacetone in a ratio of 70/30 vol.\% was chosen. Suspensions based on SDC and BCZYYbO-CuO with a concentration of 10 and $15 \mathrm{~g} / \mathrm{L}$, respectively, were prepared from an accurate weighed portion of the powders and sonicated using an UZV-13/150-TH ultrasonic bath (Reltec, Yekaterinburg, Russia)with power of the generator of $210 \mathrm{~W}$ at the operating frequency of $22 \mathrm{kHz}$ for $5-125 \mathrm{~min}$ (at $25^{\circ} \mathrm{C}$ ). The temperature was controlled with a thermometer and maintained at given level of water exchange in an ultrasonic bath. Suspensions of SDC and BCZYYbO-CuO with a concentration of $1 \mathrm{~g} / \mathrm{L}$ were prepared to study the dispersed composition by the method of dynamic light scattering (DLS). Disperse composition and particle size distribution in suspensions was studied using a ZetaPlus particle size analyzer (Brookhaven Instruments Corporation, Holtsville, NY, USA). The electrokinetic zeta potential and $\mathrm{pH}$ in suspensions were measured by the electroacoustic method using a DT-300 analyzer (Dispersion Technology, Bedford Hills, NY, USA). 


\subsection{Electrophoretic Deposition of the Thin-Film Electrolyte Layers}

Electrophoretic deposition of SDC and $\mathrm{BCZYYbO-CuO} \mathrm{electrolyte} \mathrm{layers} \mathrm{was} \mathrm{per-}$ formed using a specialized software-controlled installation (IEP UB RAS, Yekaterinburg, Russia) in a constant voltage mode. The current was measured using an Intelligent Digital Multimeter UNI-T UT71E (Uni-Trend Technology, Hong Kong, China). The electrodes of the EPD cell with a diameter of $12 \mathrm{~mm}$ were placed at a distance of $10 \mathrm{~mm}$. For the deposition of the electrolyte layer an anode substrate was placed on the cathode of the EPD cell. A stainless-steel disk was used as a counter electrode of the EPD cell.

Examination of the powders' morphology and microstructure of the deposited films were performed using a JSM-6390 LA scanning electron microscope (SEM, JEOL, Tokyo, Japan) equipped with a system of energy-dispersion X-ray microanalysis (EDX). SEM images in the BSE (back-scattered electrons) and SE (secondary electrons) modes were obtained at a high voltage of $10 \mathrm{kV}$. For the EDX analysis the high voltage of $10 \mathrm{kV}$ was used as well. The morphology of thin-film layers at the stages of deposition was investigated using an ST-VS-520 optical microscope (IEP UB RAS, Yekaterinburg, Russia). The thickness of the deposited green coatings was estimated from the weight of the film, the surface area of the substrate to be coated with the film, and the theoretical density of the deposited material. The thickness of the sintered coating was determined from the cross-section SEM images.

\section{Results and Discussion}

\subsection{Characteristics of Electrolyte Powder Materials}

The XRD patterns of the resulting SDC and BCZYYbO powders are shown in Figure 1 (Supplementary Materials Figure S1). According to the XRD data, the sample of the microsized SDC powder was single-phase that possessed a cubic type structure of Fm-3m (225) space group with a lattice parameter of $a=5.4305(1) \AA$. The BCZYYbO powder sample was single-phase and had a rhombohedral crystal lattice with an R-3c (167) space group and the lattice parameters $a=6.1330(3) \AA, b=6.1330(3) \AA, c=14.9910(1) \AA$. The $\mathrm{BCZYYbO}-\mathrm{CuO}$ powder was subjected to the XRD analysis after sintering at $1500{ }^{\circ} \mathrm{C}$. It was found that $\mathrm{CuO}$ modified $\mathrm{BCZYYbO}$ preserved a rhombohedral structure with an R-3c space group, however the lattice parameters were lower due to partial copper dissolution in the structure $(a=6.0972(3) \AA, b=6.0972(3) \AA, c=14.9370(1) \AA)$. Such $a$ decrease agrees well with that observed in [47] for $\mathrm{BaCe}_{0.3} \mathrm{Zr}_{0.55} \mathrm{Y}_{0.15} \mathrm{O}_{3-\delta}$ modified by different sintering additives including $\mathrm{CuO}$. In addition to the main $\mathrm{BCZYYbO}$ phase, the presence of secondary phases of $\mathrm{CuO}, \mathrm{BaO}$ and was registered on the $\mathrm{XRD}$ of the sintered $\mathrm{BCZYYbO-CuO} \mathrm{powder} \mathrm{(Figure} \mathrm{1c).}$

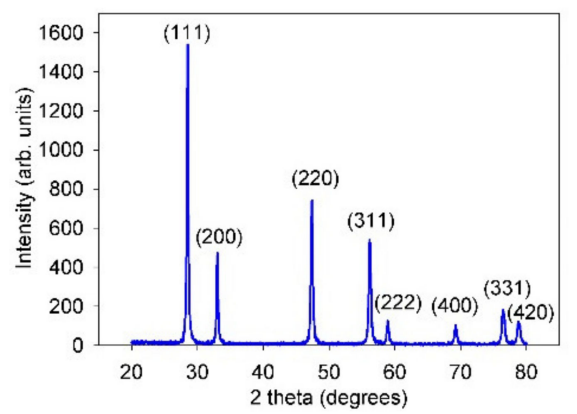

(a)

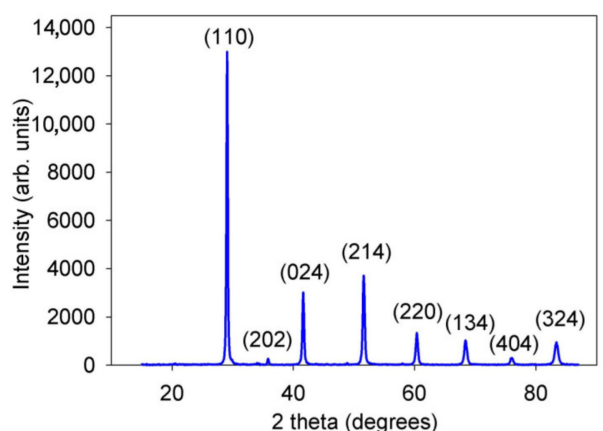

(b)

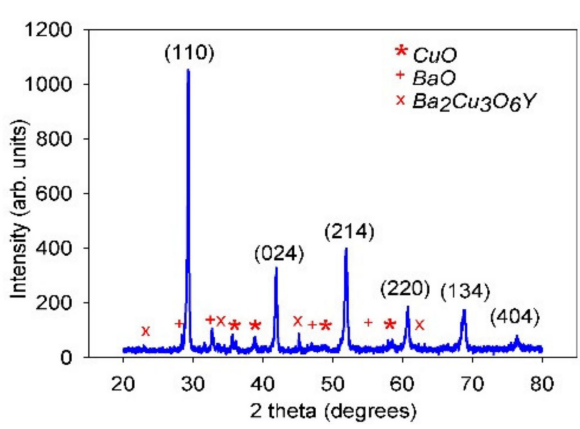

(c)

Figure 1. XRD patterns obtained for the electrolyte powders: (a) as-prepared SDC powder; (b) as-prepared BCZYYbO powder; (c) BCZYYbO-CuO powder (sintered at $1500^{\circ} \mathrm{C}$ ).

The powders morphology investigated using SEM method is shown in Figure 2. It can be seen that the powders have a similar size of irregular aggregates $\sim 2-4 \mu \mathrm{m}$, consisting of 
tightly linked smaller particles. However, SDC powder (Figure 2a) has a more developed surface of particle aggregates which is confirmed by the values of the specific surface area. The average particle radius, assuming the presence of loosely packed aggregates characteristic of SCS powders, can be calculated as follows [48]:

$$
\mathrm{R}_{\mathrm{BET}}=\frac{3 \times 10^{-6}}{\rho_{\mathrm{th}} \mathrm{S}_{\mathrm{BET}}}
$$

where $\rho$ th is the theoretical material density calculated from the XRD data. The calculated $\mathrm{R}_{\mathrm{BET}}$ values for the SDC and BCZYYbO powders were 35 and $366 \mathrm{~nm}$, respectively. $\mathrm{S}_{\mathrm{BET}}$ is the specific surface area of the powders defined using the BET method.

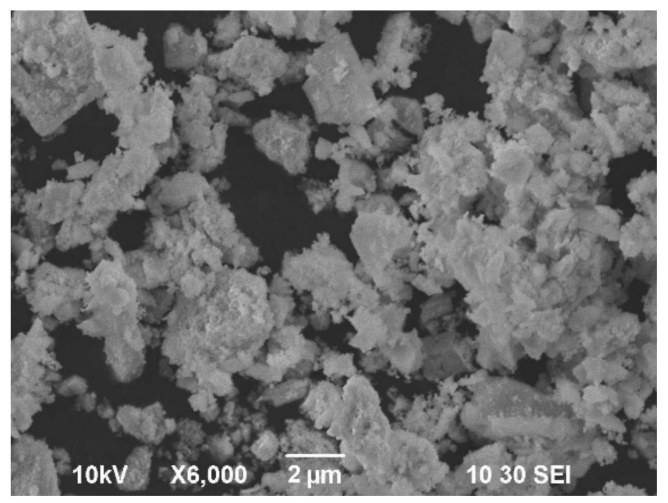

(a)

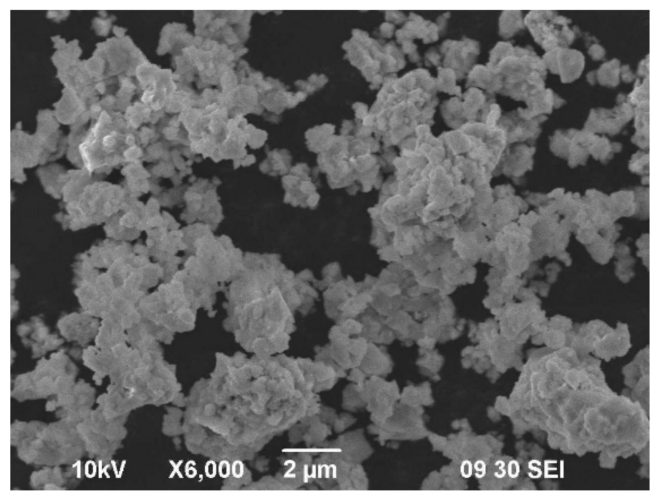

(b)

Figure 2. Morphology of as-prepared powders: (a) $\mathrm{SDC}\left(\mathrm{T}_{\text {calc }}=900{ }^{\circ} \mathrm{C}\right)$; (b) $\mathrm{BCZYYbO}$ $\left(\mathrm{T}_{\text {calc }}=1100^{\circ} \mathrm{C}\right)$.

\subsection{Fractional Composition and Electrokinetic Potential of the Suspensions of the Powder} Electrolyte Materials

The disperse composition was studied by the DLS method in the suspensions of the BCZYYbO-CuO and SDC powders with a concentration of $1 \mathrm{~g} / \mathrm{L}$ in the isopropanol/ acetylacetone (70/30 vol.\%) medium. Figure 3 shows the dependence of the effective hydrodynamic diameter of the aggregates $\left(\mathrm{d}_{\text {eff }}\right)$ for the suspensions in dependence on the time of the ultrasonic treatment (UST) under continuous cooling of the suspension. The initial $d_{\text {eff }}$ values for the BCZYYbO-CuO and SDC suspensions were determined to be equal to 1150 and $1503 \mathrm{~nm}$, respectively. After $25 \mathrm{~min}$ of UST, $\mathrm{d}_{\text {eff }}$ increased for both BCZYYbO-CuO and SDC suspensions to 1275 and $1687 \mathrm{~nm}$, respectively. However, with further increasing the UST time, the size of aggregates decreased, and this tendency was more pronounced for the SDC suspension. Thus, for the BCZYYbO-CuO and SDC suspensions treated ultrasonically for $125 \mathrm{~min}_{\text {eff }}$ was reduced to the values of 1043 and $732 \mathrm{~nm}$, respectively.

Figure 4 demonstrates the unimodal distributions of particles by the scattering intensity of the BCZYYbO-CuO (Figure 4a) and SDC (Figure 4b) suspensions after sonication for $5,25,75$, and $125 \mathrm{~min}$. For both suspensions, after $25 \mathrm{~min}$ of the UST, the distributions broadened; with a further increase in the UST time, the distributions narrowed, which is characterized by the values of the geometric standard deviation (GSD). For the BCZYYbO$\mathrm{CuO}$ suspension after UST for 5, 25, 75, and $125 \mathrm{~min}$ the GSD values were $1.44 \pm 0.07$, $1.57 \pm 0.07,1.54 \pm 0.07$, and $1.52 \pm 0.07$, respectively. While for the SDC suspension after UST for 5, 25, 75, and $125 \mathrm{~min}$, the GSD values were $1.68 \pm 0.07,1.71 \pm 0.07,1.57 \pm 0.07$, and $1.53 \pm 0.07$, respectively. 


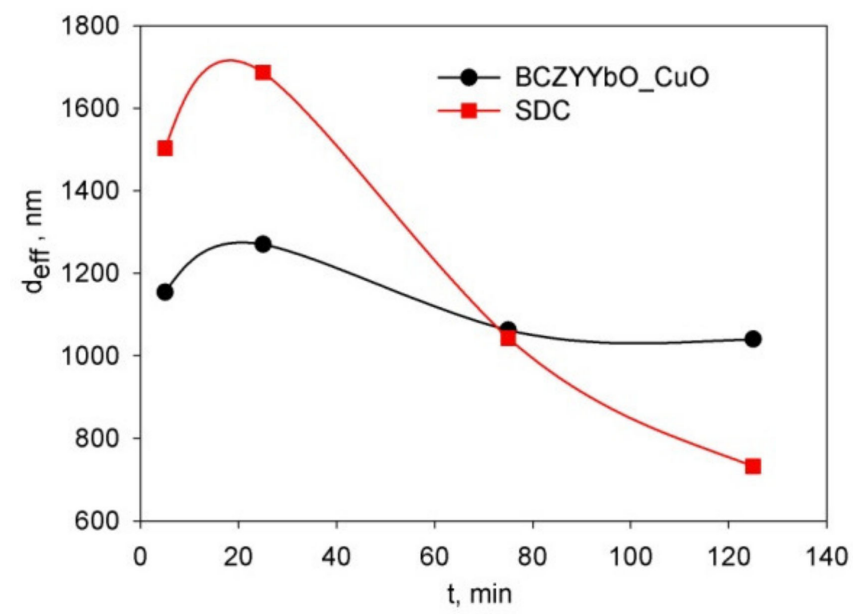

Figure 3. Schemes follow the same formatting. Dependence of the effective hydrodynamic diameter of aggregates, $\mathrm{d}_{\text {eff }}$, in the suspensions of the BCZYYbO-CuO and SDC powders on the time of the ultrasonic treatment carried out under continuous cooling.

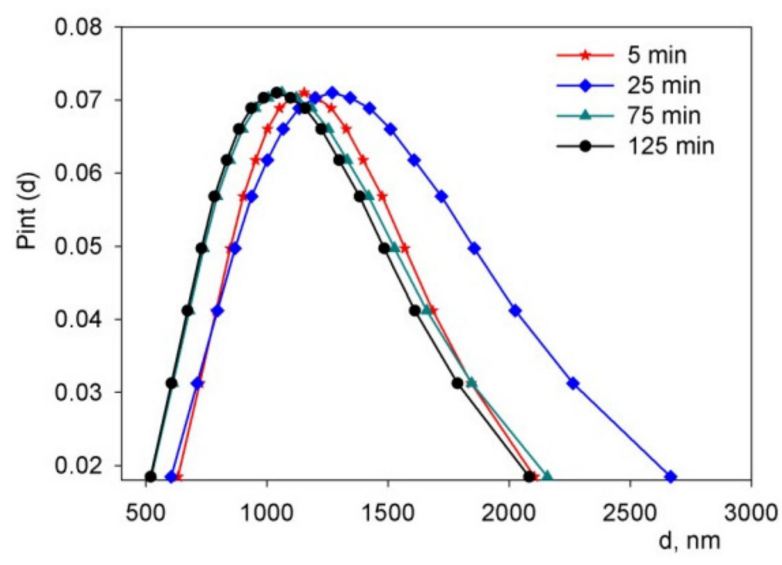

(a)

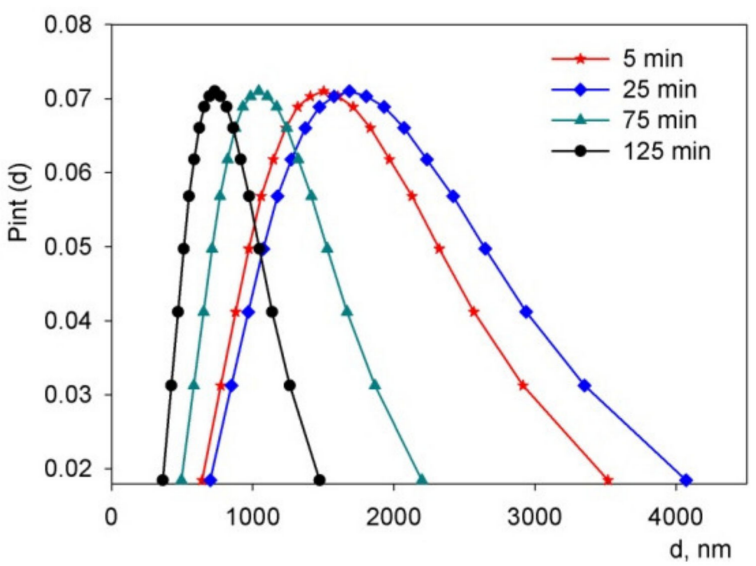

(b)

Figure 4. Unimodal distributions of the aggregate size in suspensions after ultrasonic treatment for 5, 25, 75, and 125 min: (a) BCZYYbO-CuO; (b) SDC. $\mathrm{P}_{\text {int }}($ d) is a probability density of unimodal distribution of aggregates by size.

The results of studying the fractional composition for the BCZYYbO-CuO (Figure 5a) and SDC (Figure 5b) suspensions revealed that the initial suspensions (after UST for $5 \mathrm{~min}$ ) BCZYYbO-CuO and SDC contained one fraction of aggregates with a size of 1325 and $755 \mathrm{~nm}$, respectively. After UST for $125 \mathrm{~min}$, the distribution of aggregates in both suspensions changed, namely, they became bimodal. A fine fraction of aggregates with a size of $745 \mathrm{~nm}(74 \%)$ and a larger fraction with a size of $1960 \mathrm{~nm}(26 \%)$ appeared in the $\mathrm{BCZYYbO}-\mathrm{CuO}$ suspension. In the SDC suspension, the fractional composition was characterized by the presence of $492 \mathrm{~nm}(47 \%)$ and $1662 \mathrm{~nm}(53 \%)$ fractions.

The $\zeta$-potential and $\mathrm{pH}$ values measured in this study in the $\mathrm{BCZYYbO}-\mathrm{CuO}$ and SDC suspensions were equal to $+11 \mathrm{mV}(6.1 \mathrm{pH})$ and $+13 \mathrm{mV}(2.9 \mathrm{pH})$, respectively. Despite the relatively low values of the $\zeta$-potential, the suspensions are characterized by aggregative stability which made it possible to carry out the EPD process [49]. 


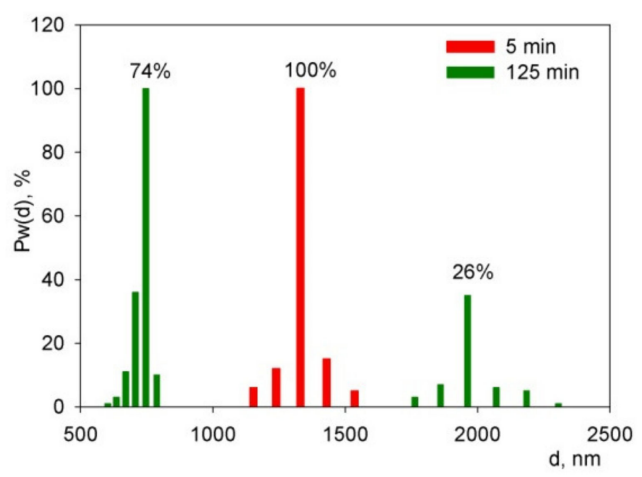

(a)

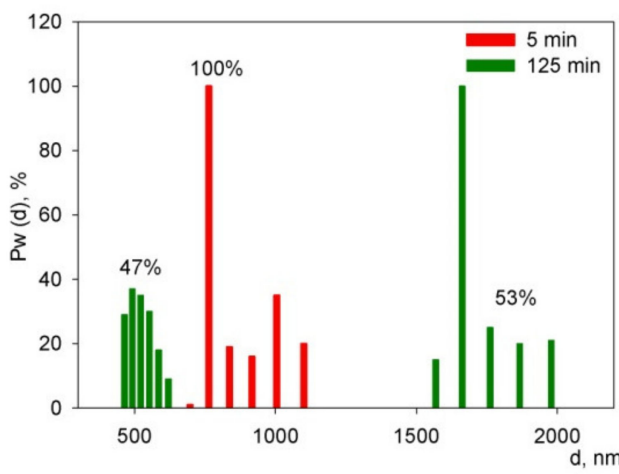

(b)

Figure 5. Fractional composition after the ultrasonic treatment for 5 and $125 \mathrm{~min}$ in suspensions: (a) the $\mathrm{BCZYYbO}-\mathrm{CuO}$; (b) SDC. $\mathrm{P}_{\mathrm{w}}(\mathrm{d})$ is a weight fraction (\%) of aggregates with a diameter $\mathrm{d}(\mathrm{nm})$.

\subsection{Investigation of EPD of Electrolyte Materials on a Model Substrate (Ni-Foil)}

Preliminary studies of the EPD process from the stabilized suspensions of the BCZYYbO$\mathrm{CuO}$ and SDC powders were carried out on a Ni-foil model substrate. Current-voltage characteristics (VAC) under increasing and decreasing voltage and kinetics of the change in the current strength for $15 \mathrm{~g} / \mathrm{L} \mathrm{BCZYYbO}-\mathrm{CuO}$ and $10 \mathrm{~g} / \mathrm{L}$ SDC suspensions were studied. VAC of the SDC suspension is characterized by slight nonlinearity and hysteresis with increasing and decreasing the cell voltage. No nonlinearity and hysteresis of VAC was registered in the study of the $\mathrm{BCZYYbO}-\mathrm{CuO}$ suspension, which corresponds to the absence of a dependence of the electrophoretic mobility of particles in the suspension on the electric field strength.

For the EPD of the electrolyte layer from the suspensions of BCZYYbO-CuO (cell voltage $80 \mathrm{~V}$ ) and SDC (cell voltage $60 \mathrm{~V}$ ), the dependences of the current strength on time are shown in Figure 6. For the $\mathrm{BCZYYbO}-\mathrm{CuO}$ suspension, there is a clear tendency to a decrease in the current strength with time, while the SDC suspension is characterized by an alternating change in the current with time-in the initial period of the process (up to $2 \mathrm{~min}$ ) the current sharply increases and then gradually decreases with time (Figure 6).

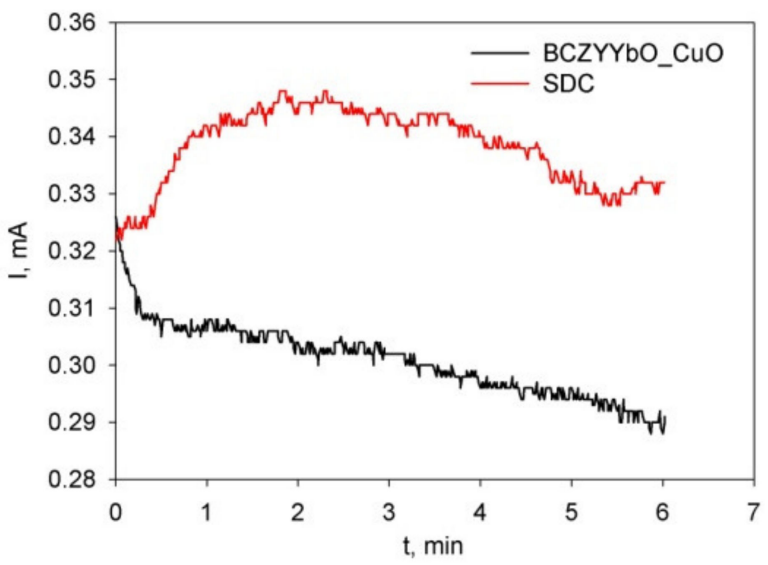

Figure 6. Dependence of the current strength on time for EPD from a suspension of BCZYYbO-CuO $(15 \mathrm{~g} / \mathrm{L})$ (cell voltage $80 \mathrm{~V}$ ) and $10 \mathrm{~g} / \mathrm{L} \mathrm{SDC} \mathrm{(cell} \mathrm{voltage} 60 \mathrm{~V}$ ).

During the deposition of the $\mathrm{BCZYYbO-CuO}$ and SDC coatings the deposition voltage was varied from 10 to $100 \mathrm{~V}$ at a constant deposition time for $1 \mathrm{~min}$ (Figure 7). The dependences of the deposit weight for both $\mathrm{BCZYYbO-CuO}$ and SDC suspensions with increasing voltage had a nonlinear character of increase, close to S-shaped. 


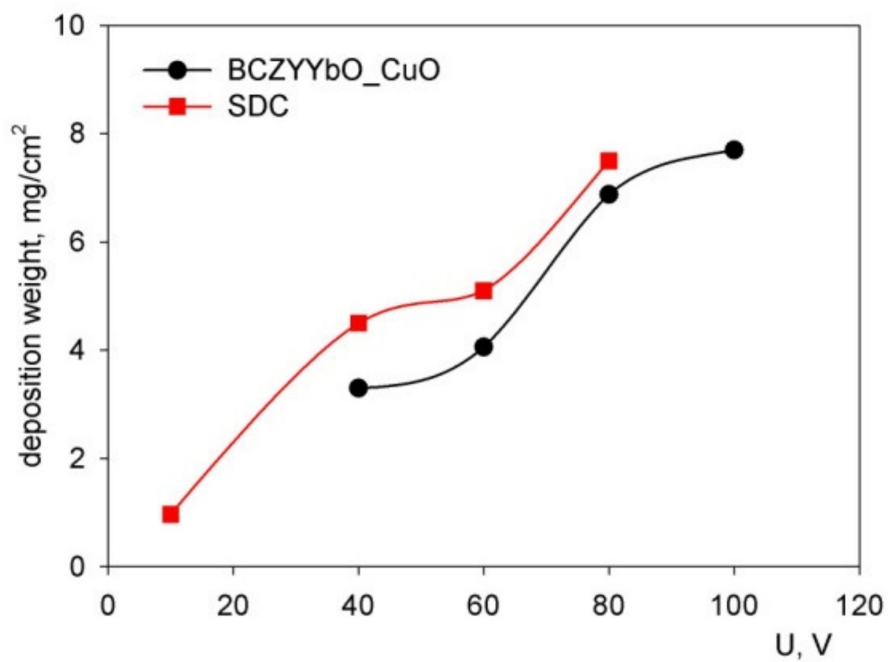

Figure 7. Dependence of the deposit weight of the BCZYYbO-CuO and SDC coatings on the deposition voltage at a constant EPD time (1 min).

\subsection{Formation of an Electrolyte Layer on Porous Anode Substrates by the EPD Method}

\subsubsection{Direct EPD on Non-Conductive Porous Substrates}

Based on the results of EPD on non-conductive porous anodes presented in the study of Besra et al. [50], we carried out a series of experiments in which a porous nonconductive substrate (cermet anode) was placed on a metal electrode (cathode) of the EPD cell and a stainless-steel plate served as a counter electrode. As noted in [50], the deposition mechanism in this case is the presence of continuous pores in the substrate structure assuring conductive paths between the particles in the suspension with the electrode. The presence of such through conductive paths is a key factor that determines the implementation of deposition, and the value of porosity significantly affects the deposit weight. For instance, at EPD with a voltage of $100 \mathrm{~V}$ for $3 \mathrm{~min}$, the authors obtained an $\left(\mathrm{ZrO}_{2}\right)_{0.92}\left(\mathrm{Y}_{2} \mathrm{O}_{3}\right)_{0.08}(\mathrm{YSZ})$ electrolyte coating of approximately $27 \mathrm{mg} / \mathrm{cm}^{2}(40 \mu \mathrm{m})$ on a $\mathrm{NiO}-\mathrm{YSZ}$ cermet substrate with porosity of $72.55 \%$. In this study the porosity of the anode substrates did not exceed $35 \%$; therefore, we increased the deposition voltage and carried out experiments on EPD at a voltage across the electrodes of $250 \mathrm{~V}$ and a deposition time of $3 \mathrm{~min}$.

Figure 8 presents optical photographs of the EPD deposits obtained from the suspensions of the BCZYYbO-CuO (Figure 8a) and SDC (Figure $8 b$ ) powders. The deposit weight was $1.5 \mathrm{mg} / \mathrm{cm}^{2}(\mathrm{BCZYYbO}-\mathrm{CuO})$ and $2.3 \mathrm{mg} / \mathrm{cm}^{2}$ (SDC). It can be seen that for both suspensions there was no formation of continuous deposited layers. Probably, this is due to the appearance of deposition instability when the levelling of the thickness of the deposited coating does not occur, and an island structure of the deposit is realized. Possible factors affecting the unevenness of the coating during deposition are uneven distribution of porous conducting channels of the non-conductive substrate, fluctuations in the electric field strength near the substrate surface, and the occurrence of electrohydrodynamic flows [51,52].

Since we identified the problem of the continuity of the deposited layer on a nonconductive anode substrate, we identified as a key task the creation of uniform conductivity over the entire surface of the substrate and providing electrical connection with an external voltage source. 


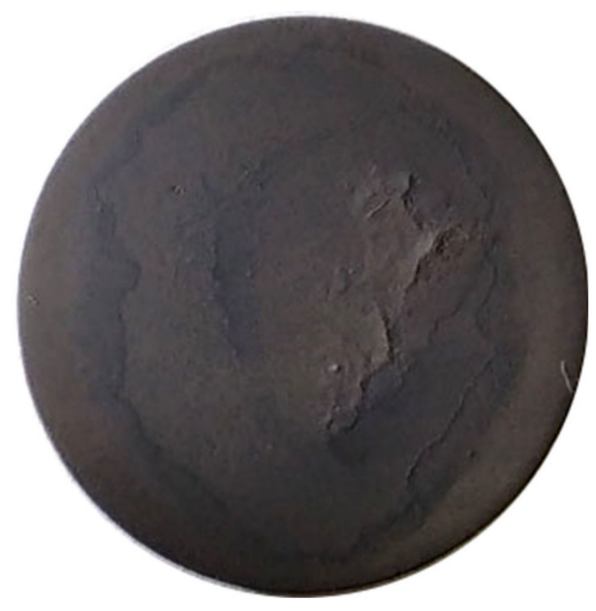

(a)

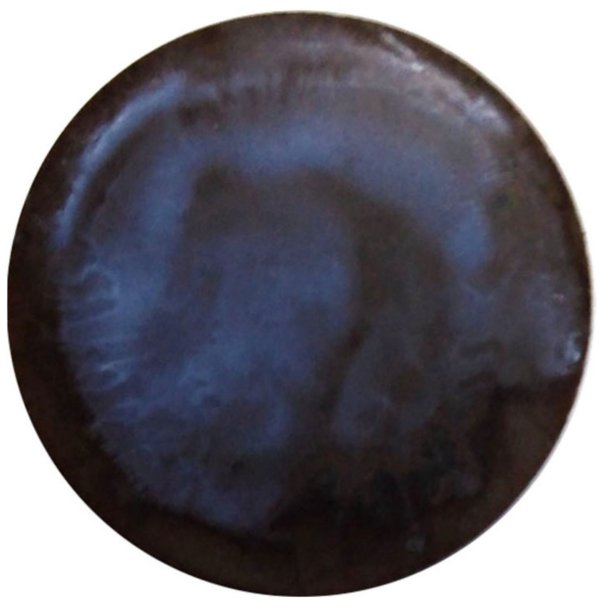

(b)

Figure 8. Optical photographs of EPD deposits obtained by direct deposition on porous NiO-SDC cermet substrates from the suspensions based on powders: (a) BCZYYbO-CuO; (b) SDC.

\subsubsection{EPD on Reduced NiO-SDC Substrates}

EPD of a Two-Layer BCZYYbO-CuO/SDC Electrolyte on a Reduced NiO-SDC Anode Substrate

As one of the methods for creating the conductivity across the entire NiO-SDC substrate, its reduction in a $\mathrm{H}_{2}$-containing atmosphere was chosen. The reduction was performed during $80 \mathrm{~min}$ in a $\mathrm{H}_{2}(5 \mathrm{vol} . \%) / \mathrm{Ar}$ mixture at a temperature of $650{ }^{\circ} \mathrm{C}$. EPD of the layer of the proton-conducting electrolyte $\mathrm{BCZYYbO-CuO}$ was carried out at $80 \mathrm{~V}$ for $1 \mathrm{~min}$. The obtained coating of $4.4 \mathrm{mg} / \mathrm{cm}^{2}$ with a thickness of $7.8 \mu \mathrm{m}$ was sintered in air at a temperature of $1300{ }^{\circ} \mathrm{C}$ for $2 \mathrm{~h}$. Then, the anode-substrate was re-reduced under the conditions described above and the SDC layer was deposited at $100 \mathrm{~V}$ for $2 \mathrm{~min}$. The deposited weight of the SDC layer was $3.4 \mathrm{mg} / \mathrm{cm}^{2}$ and the thickness was $4.7 \mu \mathrm{m}$. Thus, the presence of the pre-sintered $\mathrm{BCZYYbO}-\mathrm{CuO}$ possessing relatively low conductivity at room temperature resulted in a decrease in the deposition rate of the SDC electrolyte layer. Nevertheless, the deposition was performed successfully due to conducting properties of the reduced substrate. The obtained two-layer coating was dried in air at a room temperature for $24 \mathrm{~h}$. According to the observation using the optical microscope, as-prepared two-layer coating was uniform without any pores and cracks (Figure 9a). Sintering of the two-layer electrolyte structure was carried out at a temperature of $1400^{\circ} \mathrm{C}$ for $5 \mathrm{~h}$. After the sintering, multiple breaks occurred in the electrolyte layer (Figure $9 \mathrm{~b}$ ) and a significant curvature of the substrate was also observed. The control of the change in the weight and linear dimensions of the substrates during the reduction-oxidative sintering cycles was carried out on the test sample. Reduction of the anodes led to a decrease in their weight by $14 \%$. The subsequent oxidative sintering led to an increase in their weight by $14 \%$ as well. The change in linear dimensions of the test sample was of the order of $10 \%$. It can be concluded that the cycles of reduction-oxidative sintering are accompanied by a significant change in the specific volume of nickel oxide in the composition of the anode which is in agreement with the data presented in [53]. Due to repetitive redox cycles, the appearance of bending mechanical stresses in the substrate caused by different redox behavior of the $\mathrm{NiO}$ and SDC is also possible [54]. When the anode-substrate was reduced, the gas permeability coefficient of the anode substrate increased from $1.6 \times 10^{-3}$ to $7.9 \times 10^{-3} \mu^{2}$. After oxidative sintering at $1400{ }^{\circ} \mathrm{C}$ for $5 \mathrm{~h}$ the gas permeability coefficient decreased to $2.5 \times 10^{-3} \mu \mathrm{m}^{2}$. 


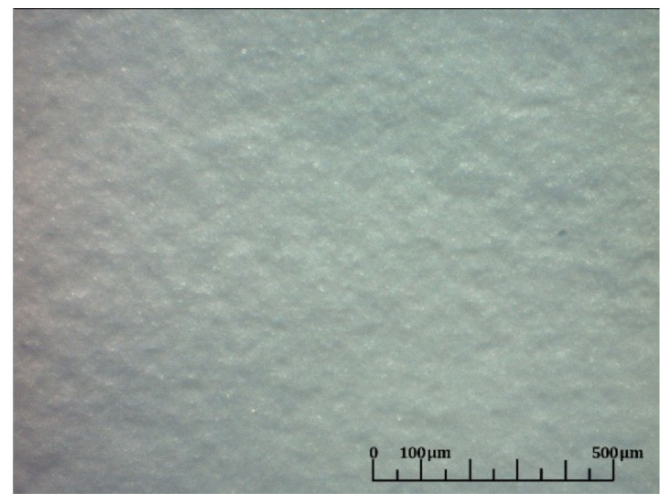

(a)

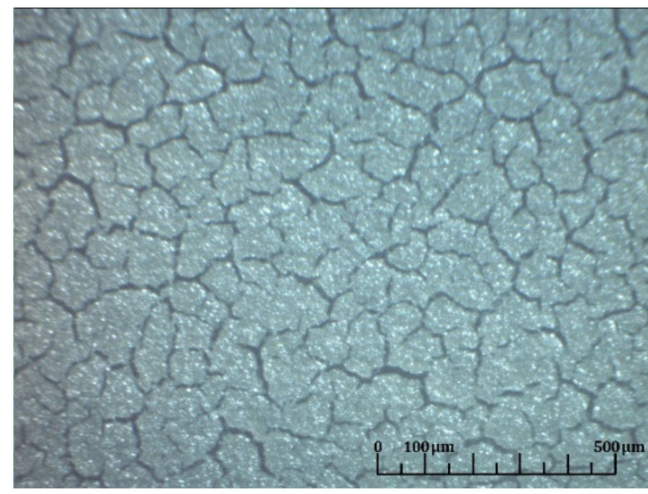

(b)

Figure 9. Optical photographs of the surface of the deposited two-layer electrolyte BCZYYbOCuO/SDC: (a) after deposition and drying of the SDC layer; (b) and after sintering in air at a temperature of $1400^{\circ} \mathrm{C}$ for $5 \mathrm{~h}$.

\section{EPD of a Single-Layer SDC Electrolyte on a Reduced NiO-SDC Anode Substrate}

To elucidate factors that determine the continuity of the sintered coating, we excluded the BCZYYbO-CuO barrier layer, and carried out the formation of a single-layer SDC electrolyte directly on the reduced anode substrate, followed by the oxidative sintering. The SDC layer was deposited at $100 \mathrm{~V}$ for $5 \mathrm{~min}$. The deposited weight was $6.3 \mathrm{mg} / \mathrm{cm}^{2}$ and the coating thickness was $8.7 \mu \mathrm{m}$. During sintering at a temperature of $1400{ }^{\circ} \mathrm{C}$ for $5 \mathrm{~h}$, the substrate broke into several fragments. On the separate fragments of the substrate, the SDC electrolyte layer with multiple breaks in it was observed, as in the sample with the two-layer film (Figure 9b). Thus, it can be concluded that the main factor preventing the formation of a continuous electrolyte layer during its sintering, in this case, is the reduction of the anode-substrate and its subsequent oxidative sintering, which causes significant mechanical stresses in the substrate-electrolyte structure up to its complete destruction.

Figure 10 shows dilatometric curves for initial powder materials (Figure 10a,b) and anode substrates (Figure 10c). The material BCZYYbO-CuO (Figure 10a) is characterized by complex behavior during heating and subsequent cooling. When heated to a temperature of about $900{ }^{\circ} \mathrm{C}$, thermal expansion of the material occurred, which was followed by short-term compaction in the temperature range of $900-1000{ }^{\circ} \mathrm{C}$. Then a sharp expansion of the material occurred and continued until the end of heating up to $1500{ }^{\circ} \mathrm{C}$, which may be associated with ongoing transformations in the material probably connected with incorporation of $\mathrm{Cu}$ into the lattice. Upon subsequent cooling, a slight shrinkage was followed by a slight expansion at a temperature of about $900{ }^{\circ} \mathrm{C}$. The size of the BCZYYbO$\mathrm{CuO}$ sample increased during the heating-cooling temperature cycle and the $\mathrm{dL} /$ Lo value was about +0.3 . A sample of powder material SDC (Figure 10b) showed a different behavior: primary thermal expansion was followed by sintering and compaction of the material at temperatures of $800-1450{ }^{\circ} \mathrm{C}$. Upon cooling, thermal contraction of the material occurred. There was a decrease in the size of the SDC sample during the heating-cooling temperature cycle and the $\mathrm{dL} / \mathrm{L}_{\mathrm{o}}$ value was about -0.12 . For unreduced anode substrates (Figure 10c), compaction was observed in the temperature range from 1160 to $1300{ }^{\circ} \mathrm{C}$. Cooling was accompanied by thermal contraction of the material. The reduced anode substrate (Figure 10c) experienced a sharp expansion, exceeding thermal expansion in the temperature range of $500-845^{\circ} \mathrm{C}$, which was followed by shrinkage when heated to a temperature of $1300{ }^{\circ} \mathrm{C}$. Upon cooling, a uniform compression of the material occurred, and there was no total change in the dimensions during the temperature cycle. The revealed features of the behavior of the applied powder materials during heating and cooling can be a determining factor affecting the sintering process of the formed EPD coatings. 


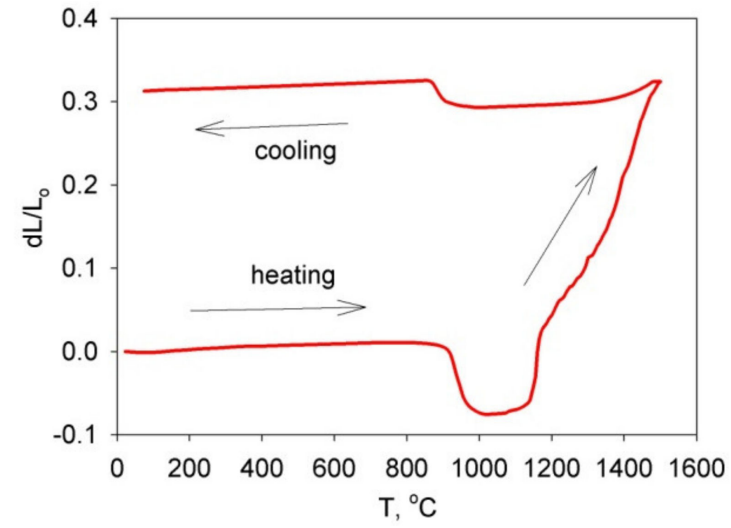

(a)

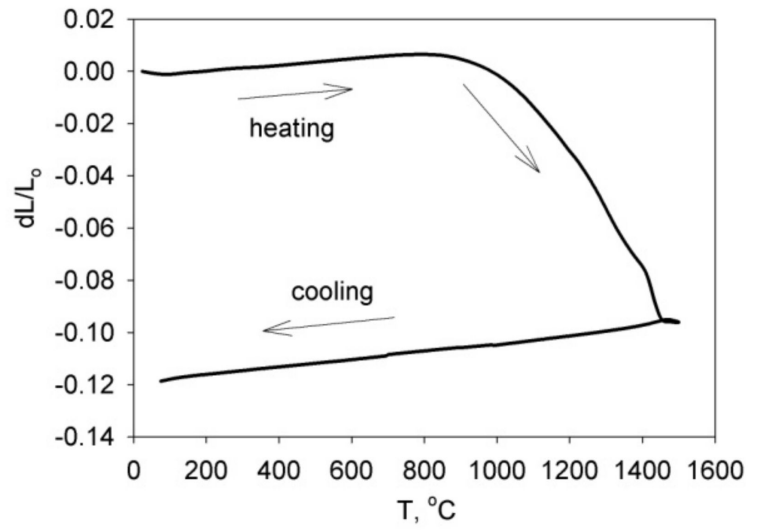

(b)

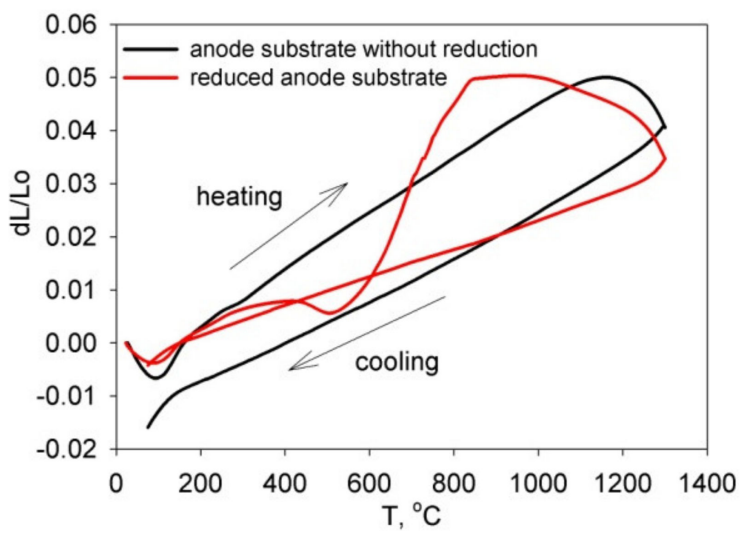

(c)

Figure 10. Dilatometric curves: (a) for the compacted BCZYYbO-CuO powder; (b) for the compacted SDC powder; (c) for as-prepared and reduced anode substrates.

\subsubsection{EPD on Porous Anodes with a Conductive Pt Sublayer}

Further experiments on the formation of an SDC electrolyte layer by EPD were conducted on the NiO-SDC anode substrates with a conductive coating on its surface. A new method of surface modification was proposed by the deposition of a platinum layer on the front surface of the NiO-SDC substrates from a suspension of Pt particles in isopropanol followed by drying and annealing at a temperature of $900^{\circ} \mathrm{C}$ for $1 \mathrm{~h}$ was performed. The platinum layer weight was $13.3 \mathrm{mg} / \mathrm{cm}^{2}$. Then, EPD of the SDC electrolyte layer was performed on the surface of the anode substrate with the applied platinum sublayer (at the EPD mode: voltage $100 \mathrm{~V}$, time $2 \mathrm{~min}$ ) by sequentially carrying out four depositionsintering cycles with an increase in the total electrolyte thickness up to $32.7 \mu \mathrm{m}$ during final sintering at a temperature of $1500^{\circ} \mathrm{C}, 5 \mathrm{~h}$ (Table 2).

At the third stage, after sintering at $1450{ }^{\circ} \mathrm{C}$, for $5 \mathrm{~h}$, SEM examination of the surface of the SDC electrolyte film was performed (Figure 11).

It can be seen that there was no complete sintering of the SDC electrolyte layer at a temperature of $1450{ }^{\circ} \mathrm{C}$ for $5 \mathrm{~h}$, namely, there were sintered areas of the coating about $10 \mu \mathrm{m}$ in size with grains of about $3 \mu \mathrm{m}$ in size, separated by pores and their clusters about 5-10 $\mu \mathrm{m}$ in size (Figure 11a). According to the EDX analysis, no platinum was detected on the surface of the sintered layer of SDC electrolyte (Figure 11b,c). There are only SDC electrolyte elements in an amount close to the nominal one: Ce- 28 at. \%, Sm-7 at. $\%, \mathrm{O}-65$ at.\%. It can be concluded that the deposition of a single conducting Pt layer at the first stage allows the deposition of a multilayer coating containing pre-sintered low conducting layers. 
Table 2. Cycles of deposition-sintering of the SDC electrolyte layer on the NiO-SDC anode substrate with a platinum sublayer: thickness, sintering modes and the electrolyte film properties.

\begin{tabular}{ccccc}
\hline Stage & $\begin{array}{c}\text { Thickness of the } \\
\text { Electrolyte Film } \\
\text { Deposited at a } \\
\text { Given Stage, } \mu \mathrm{m}\end{array}$ & $\begin{array}{c}\text { Total Thickness } \\
\text { of the Electrolyte } \\
\text { Film, } \mu \mathrm{m}\end{array}$ & $\begin{array}{c}\text { Sintering Mode } \\
\text { at a Given Stage }\end{array}$ & $\begin{array}{c}\text { Electrolyte Film } \\
\text { Properties }\end{array}$ \\
\hline 1 & 8.0 & $1400{ }^{\circ} \mathrm{C}, 3 \mathrm{~h}$ & $\begin{array}{c}\text { Loose, porous } \\
\text { coating, no breaks in } \\
\text { the film }\end{array}$ \\
\hline 3 & 7.3 & 15.3 & $1400^{\circ} \mathrm{C}, 3 \mathrm{~h}$ & $\begin{array}{c}\text { Loose, porous } \\
\text { coating, no breaks in } \\
\text { the film }\end{array}$ \\
\hline 4 & 8.2 & 23.5 & $1450{ }^{\circ} \mathrm{C}, 5 \mathrm{~h}$ & $\begin{array}{c}\text { Porous coating, no } \\
\text { breaks in the film }\end{array}$ \\
\hline & 9.2 & $150{ }^{\circ} \mathrm{C}, 5 \mathrm{~h}$ & $\begin{array}{c}\text { No breaks in the } \\
\text { film }\end{array}$ \\
\hline
\end{tabular}

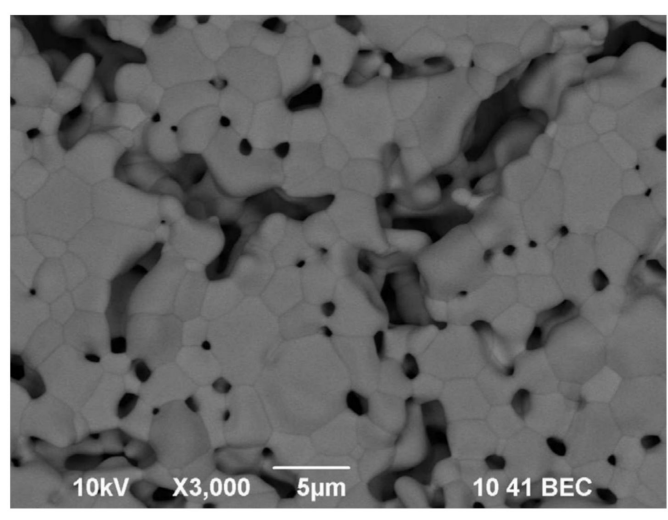

(a)

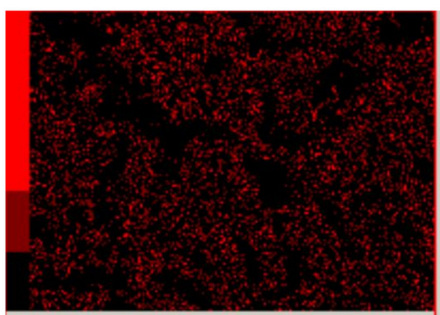

$\square 10 \mu \mathrm{m}$

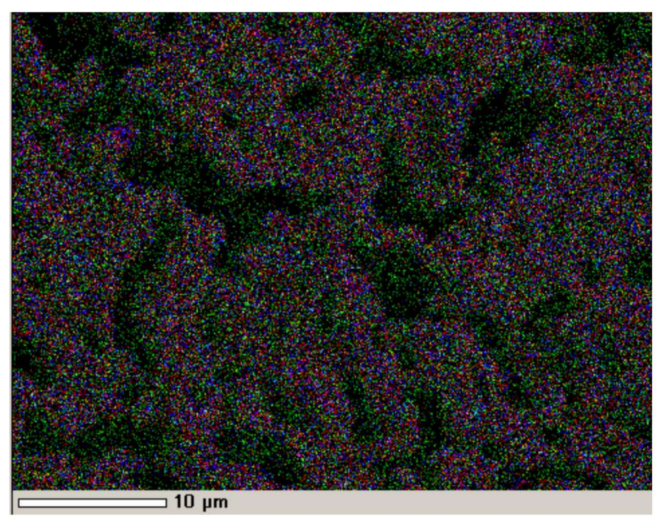

(b)
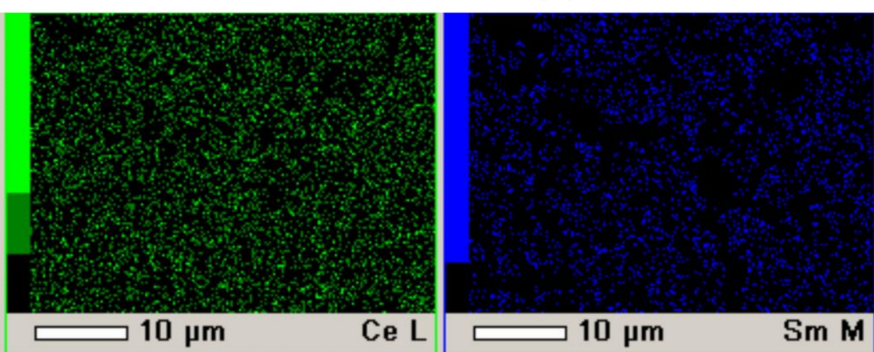

(c)

Figure 11. The surface of the SDC electrolyte layer after intermediate sintering at a temperature of $1450{ }^{\circ} \mathrm{C}$ for $5 \mathrm{~h}$ on the porous NiO-SDC anode substrate with a platinum sublayer: (a) SEM image; (b) integral map of the elements' distribution; (c) individual element maps.

Figure 12 shows a cross-section of the SDC/Pt/NiO-SDC structure after final sintering at a temperature of $1500{ }^{\circ} \mathrm{C}$ for $5 \mathrm{~h}$. It can be seen that the SDC electrolyte layer has a thickness of about $40 \mu \mathrm{m}$ and is characterized by closed porosity (Figure 12a). The elemental composition of the SDC electrolyte is presented in a nominal ratio (Figure 12b,c). The platinum layer deposited on the NiO-SDC substrate was porous and had a thickness of about $20 \mu \mathrm{m}$. Platinum was not found in the composition of the electrolyte, and the deposited Pt sublayer had no tendency to diffusion smearing during sintering (Figure S2). 


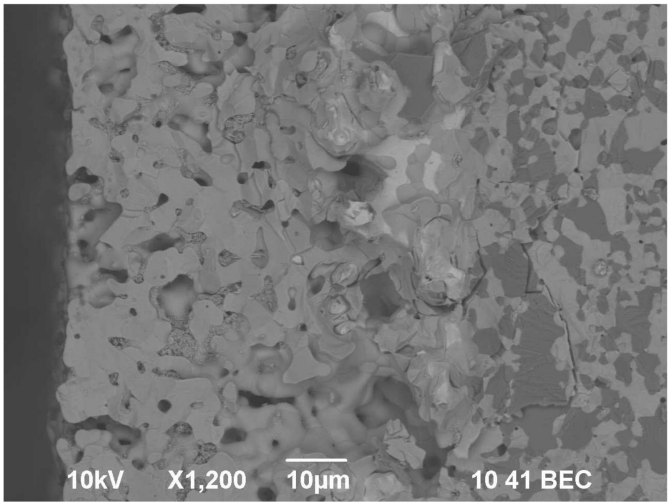

(a)

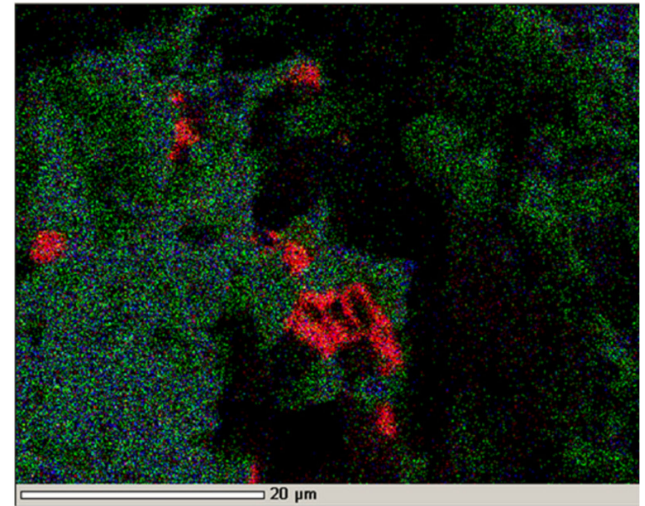

(b)

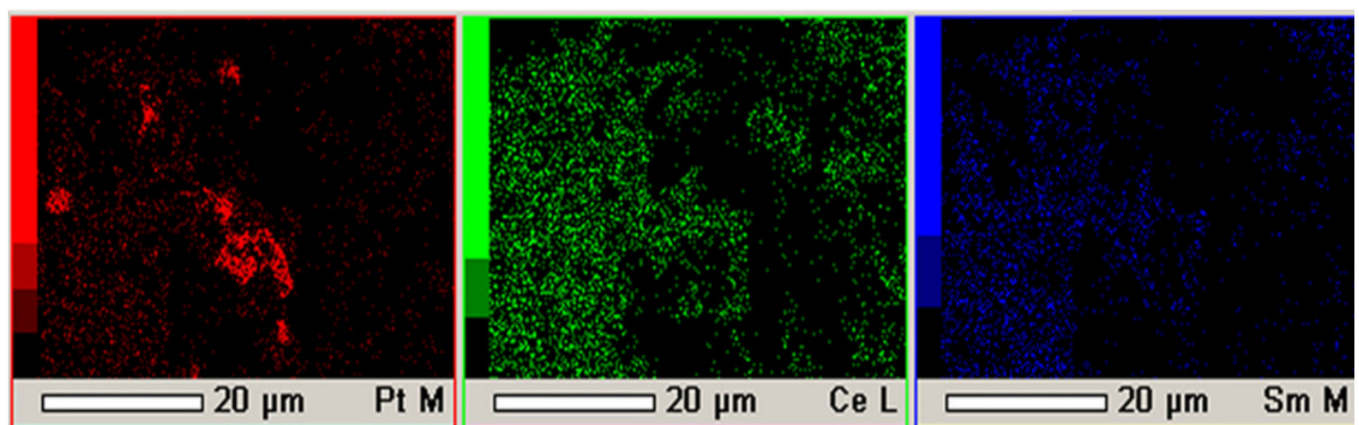

(c)

Figure 12. Cross-section of the SDC electrolyte layer after final sintering at a temperature of $1500{ }^{\circ} \mathrm{C}$ for $5 \mathrm{~h}$ on a porous anode substrate with a platinum sublayer: (a) SEM image; (b) integral map of the elements' distribution; (c) individual element maps.

3.4.4. EPD of the Single Layer SDC Electrolyte Film on the NiO-SDC Porous Substrates Pre-Sintered at Decreased Temperatures

In order to determine the possibility of reducing the sintering temperature of the SDC layer, experiments on EPD were carried out on the NiO-SDC substrates with/without the pore former pre-sintered at $1200{ }^{\circ} \mathrm{C}$ for the subsequent final co-sintering with the electrolyte layer, that, as we assumed, can contribute to its densification [27-29,41]. EPD of the SDC electrolyte layer was carried out on the anode substrates with deposited conductive layers (PPy, Pt) in a constant voltage mode of $80 \mathrm{~V}$, and the deposition time was 2 min. The experimental results are presented in Table 3 . It can be seen that the use of pre-sintered at lower temperature anode substrates with different porosity level had no a visible positive effect on the densification of the SDC electrolyte layer during its final co-sintering with the substrate at temperatures of 1450 or $1500{ }^{\circ} \mathrm{C}$. Moreover, the anode substrate formed with addition of the pore former created conditions that led to the formation of numerous cracks in the SDC electrolyte layer during co-sintering. The use of the pore-former-free substrate resulted in better quality of the SDC film sintered $1450{ }^{\circ} \mathrm{C}$, with only few single defects on its surface. An increase in the final sintering temperature from 1450 to $1500{ }^{\circ} \mathrm{C}$ eliminated surface defects, however, complete sintering of the film was not achieved. We also repeated the experiment on the pore-former-free substrate using Pt conductive coating and obtained the defect-free film at $1450{ }^{\circ} \mathrm{C}$. The use of a platinum sublayer has an advantage over the coating of the substrate with polypyrrole, since such a factor as the burnout of the conductive Ppy coating during sintering was eliminated. Thus, the SDC electrolyte film sintered at $1450{ }^{\circ} \mathrm{C}$ on the platinum sublayer possessed a denser microstructure as compared to the film obtained on Ppy. However, the effect of the type of conductive coating (Ppy, Pt) on the complete densification of the SDC layer was not observed. 
Table 3. Features of co-sintering of the SDC layer deposited on the anode porous NiO-SDC substrates pre-sintered at decreased temperatures and with different conducting layer.

\begin{tabular}{|c|c|c|c|c|}
\hline Anode Substrate & Conducting Layer & $\begin{array}{c}\text { SDC Film } \\
\text { Thickness, } \mu \mathrm{m}\end{array}$ & $\begin{array}{l}\text { SDC Film Sintering } \\
\text { Mode }\end{array}$ & $\begin{array}{l}\text { Characteristics of the } \\
\text { SDC Film Surface }\end{array}$ \\
\hline $\begin{array}{l}\mathrm{NiO}-\mathrm{SDC}+20 \% \\
\text { graphite powder }\end{array}$ & Ppy & 8 & $1450{ }^{\circ} \mathrm{C}, 5 \mathrm{~h}$ & $\begin{array}{l}\text { Unsintered film with } \\
\text { numerous edge cracks } \\
\text { (Figure 13a) }\end{array}$ \\
\hline $\mathrm{NiO}-\mathrm{SDC}$ & Ppy & 7 & $1450{ }^{\circ} \mathrm{C}, 5 \mathrm{~h}$ & $\begin{array}{l}\text { Unsintered film with few } \\
\text { cracks }\end{array}$ \\
\hline $\mathrm{NiO}-\mathrm{SDC}$ & Ppy & 7 & $1500{ }^{\circ} \mathrm{C}, 5 \mathrm{~h}$ & $\begin{array}{l}\text { Unsintered film, no } \\
\text { cracks (Figure 13b) }\end{array}$ \\
\hline $\mathrm{NiO}-\mathrm{SDC}$ & $\mathrm{Pt}$ & 8 & $1450^{\circ} \mathrm{C}, 5 \mathrm{~h}$ & $\begin{array}{l}\text { Unsintered film, no } \\
\text { cracks }\end{array}$ \\
\hline
\end{tabular}

Thus, it can be summarized that, despite the larger shrinkage of the anode substrates pre-sintered at $1200^{\circ} \mathrm{C}$, the temperature of $1500{ }^{\circ} \mathrm{C}$ is insufficient for sintering the SDC electrolyte layer. It should be noted that anode substrates with/without the pore former probably have different kinetics of changes in internal stresses during the final co-sintering with the SDC electrolyte layer, which influences the process of formation and development of cracks in the film during sintering. However, when fabricating anode-supported halfcells for SOFCs it is necessary to keep the anode porosity quite high and the use of a pore former is preferable. Additional studies should be done to find an optimal pore former content allowing the film of good quality to be obtained on the porous anode substrate.

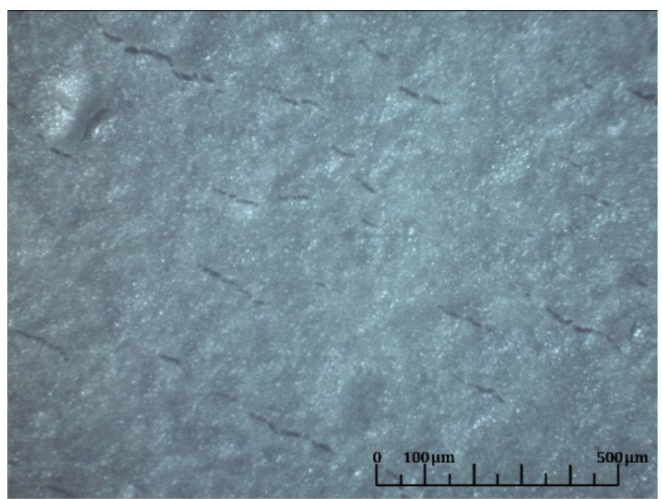

(a)

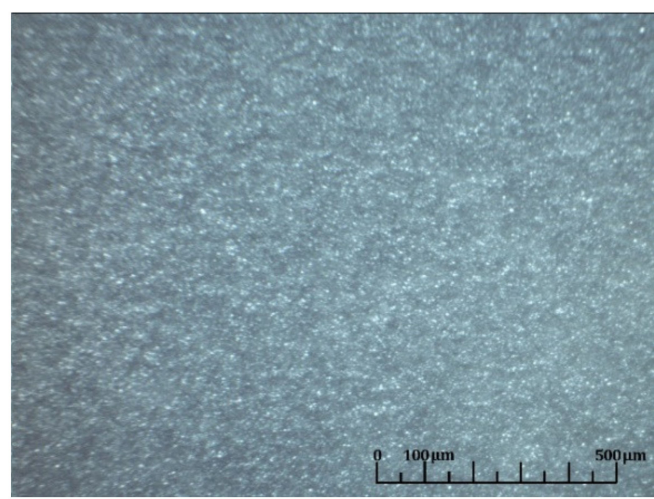

(b)

Figure 13. Optical images of the surface of the SDC films obtained after the final co-sintering: (a) at $1450{ }^{\circ} \mathrm{C}, 5 \mathrm{~h}$ with the $\mathrm{NiO}-\mathrm{SDC}$ substrate formed with the addition of $20 \mathrm{wt} . \%$ of graphite powder; (b) at $1500{ }^{\circ} \mathrm{C}, 5 \mathrm{~h}$ with the NiO-SDC substrate without the pore former.

\subsection{Microstructure of EPD Coatings Deposited on Model Ni Foil and Dense SDC Substrates}

In order to determine the reasons for the appearance of porosity in the SDC coatings sintered at the temperatures higher that that established in the dilatometry study (Figure 10b) the experiments on the deposition of an SDC coating was performed on the model Ni foil and dense SDC substrates. The structure of the SDC coating deposited on $\mathrm{Ni}$-foil and annealed at $600{ }^{\circ} \mathrm{C}$ for $1 \mathrm{~h}$ is presented in Figure 14. It can be seen that in the SDC layer there are no large pores and discontinuities, as well as ruptures and cracks. The coating is homogeneous and has a nominal elemental composition (see the EDX analysis data). As a result, it was found that the EPD process allows the formation of uniform continuous coatings of good quality, and the formation of pores in the coating takes place in the subsequent process of the coating sintering. 


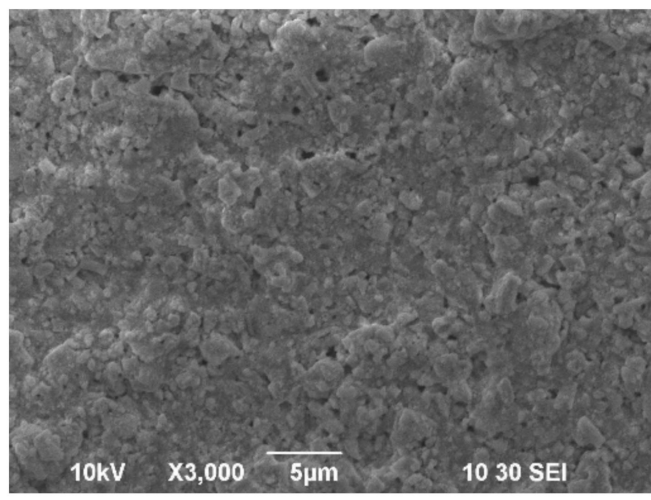

(a)

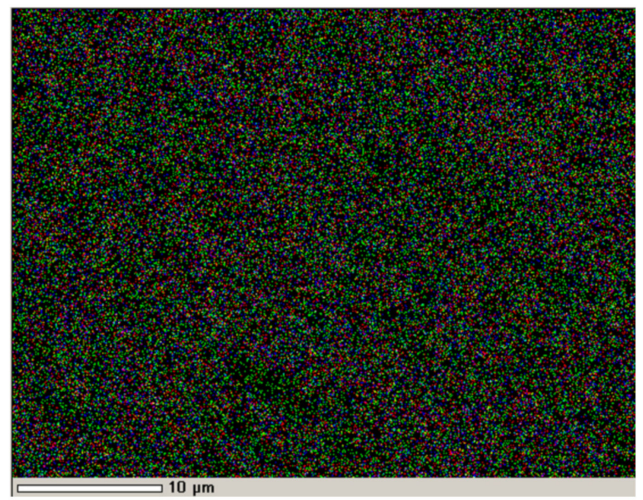

(b)
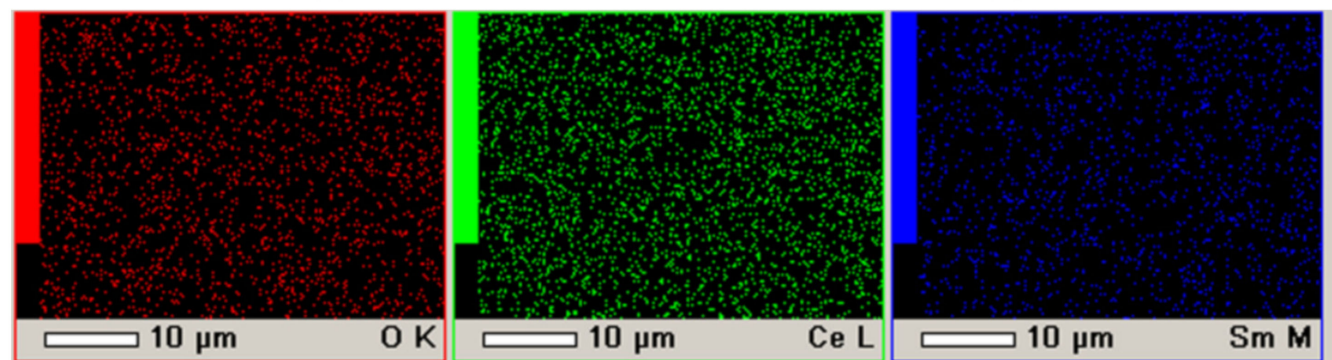

(c)

Figure 14. The surface of the layer of unsintered SDC electrolyte on a Ni-foil after annealing at a temperature of $600{ }^{\circ} \mathrm{C}$ for $1 \mathrm{~h}$ : (a) SEM image, magnification $\times 3000$; (b) integral map of the elements' distribution; (c) individual element maps.

Additional experiments on the sintering of SDC electrolyte films were carried out on a model dense SDC substrate sintered at $1600{ }^{\circ} \mathrm{C}$ for $5 \mathrm{~h}$, which was selected to determine the features of sintering and compaction of the deposited EPD layer in the absence of the substrate shrinkage. As far as the SDC conductivity is low at the room temperature, for the successful EPD similar metallization its surface was carried out by applying a Pt sublayer on the front surface of a non-conducting SDC substrate, as this method, developed in this study, gives the advantage of allowing a sequential deposition of layers with intermediate sintering. The experiment made it possible to determine the required temperature for the formation of a dense non-porous electrolyte microstructure and revealed the need for additional deposition of the coating material (SDC) after intermediate deposition and sintering $\left(1470{ }^{\circ} \mathrm{C}\right.$ for $5 \mathrm{~h}$ ) to fill the formed pores. The thickness of the SDC layer (at the voltage of $100 \mathrm{~V}$ for $6 \mathrm{~min}$ ) before intermediate sintering was $14.5 \mu \mathrm{m}$; upon sequential deposition of SDC, the coating thickness was increased to $24.3 \mu \mathrm{m}$. As can be seen in SEM images presented in Figure 15, that after the final sintering at $1550{ }^{\circ} \mathrm{C}$ for $5 \mathrm{~h}$ a dense, porefree electrolyte film was formed with the average grain size of about $25 \mu \mathrm{m}$. According to the EDX analysis, the composition of the electrolyte film corresponded to the nominal one. As a result, it was shown that the used SDC powder requires sufficiently high temperatures for final sintering into a dense electrolyte layer, as well as additional EPD of the powder material to fill the pores formed during intermediate sintering due to compaction and shrinkage of the coating material. The results obtained showed that the formation of a dense film electrolyte is not achieved only by increasing the temperature, but also requires additional introducing the material into the coating at the intermediate EPD stages. 


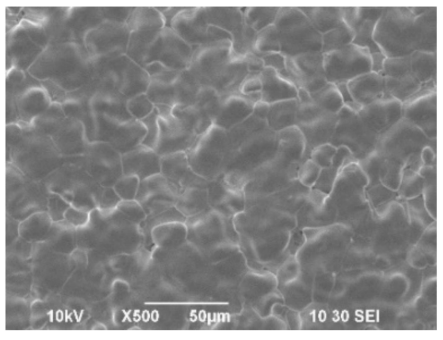

(a)

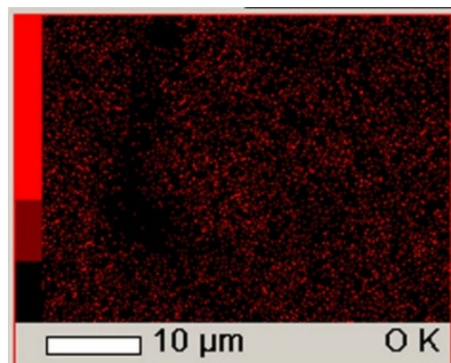

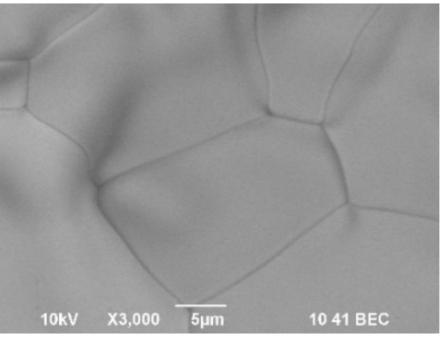

(b)

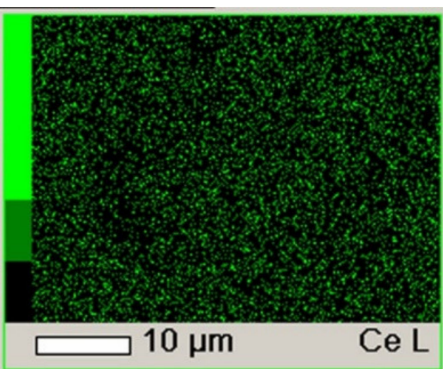

(d)

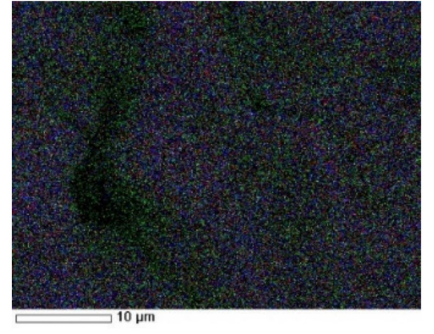

(c)

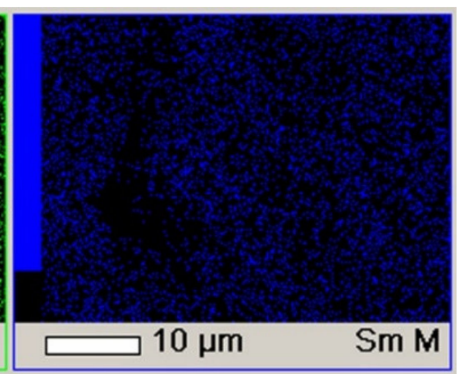

m M

Figure 15. The surface of the SDC electrolyte layer after final sintering at a temperature of $1550{ }^{\circ} \mathrm{C}$ for $5 \mathrm{~h}$ on a model dense SDC substrate with a platinum sublayer: (a) SEM image, magnification $\times 500$; (b) SEM image, magnification $\times 3000$; (c) integral map of the distribution of elements; (d) individual element maps.

\section{Conclusions}

This work presents the results of studies on the formation of thin-film SDC electrolyte and bilayer BCZYYbO-CuO/SDC electrolyte on the porous non-conducting NiO-SDC anode substrates. The work was aimed at identifying key features and possible implementations of the full technological cycle: characterization of the powders used, preparation of the suspensions based on the SDC and $\mathrm{BCZYYbO}-\mathrm{CuO}$ powder materials in a nonaqueous medium, establishment of optimal deposition modes on the model substrates, implementation of direct EPD on the porous non-conductive NiO-SDC anode substrates, EPD on the reduced Ni-SDC anode substrates, EPD on the NiO-SDC anode substrates with different conductive sublayer (PPy, Pt), and study of the sintering kinetic of the substrates and deposited layers.

The applied powders BCZYYbO and SDC were obtained by citrate-nitrate and glycinecitrate methods, respectively, which were characterized by aggregate sizes of the order of $2-4 \mu \mathrm{m}$. Analysis of the disperse, fractional composition and electrokinetic potential of the suspensions after ultrasonic treatment for 5-125 min was carried out. It was shown that the size of the aggregates in the suspension can be effectively decreased using the UST for $125 \mathrm{~min}$ down to $492 \mathrm{~nm}(47 \%)$ and $1662 \mathrm{~nm}(53 \%)$ for the SDC powder and $745 \mathrm{~nm}(74 \%)$ and $1960 \mathrm{~nm}(26 \%)$ for BCZYYbO-CuO powder, respectively.

The main difficulty in implementing EPD on non-conductive substrates is the need to create conductivity on their surface. We have investigated various possible methods to form continuous electrolyte coatings on the porous NiO-SDC substrates within the context of issues related to the subsequent sintering of the obtained electrolyte film/anode structures. It was revealed that direct EPD on the porous $\mathrm{NiO}-\mathrm{SDC}$ substrate is possible; however, a more developed porosity of the substrate is required for the formation of a continuous layer. A variant of the EPD technology, which includes deposition BCZYYbO-CuO/SDC and SDC films on the reduced Ni-SDC substrates, could not be successfully employed under our conditions due to significant mechanical stresses caused by the reduction and subsequent oxidation of both nickel and SDC in the composition of the anode substrates. This resulted in the formation of a network of breaks in the bilayer BCZYYbO-CuO/SDC 
film and complete disintegration of the single SDC film during the oxidative co-sintering with the substrate.

We have demonstrated the viability of creating PPy and Pt conducting sublayers on the NiO-SDC substrate front surface for the successful SDC electrolyte film deposition. However, the Pt conducting sublayer on the front surface of a non-conducting substrate was shown to have the advantage of allowing a sequential deposition of layers with intermediate sintering with no visible diffusion into the deposited layers.

It was demonstrated that, to obtain a gas-tight defect-free SDC electrolyte film, a higher temperature for the final sintering is required than that established in the dilatometric study of the compacted SDC powder. Moreover, it was shown that increased shrinkage of the substrates with lowered pre-sintering temperatures had no effect on the densification of the SDC electrolyte film. To preserve the porous structure of the anode substrate, a necessity for the effective operation of the SOFC, future studies should consider the possibility of reducing the sintering temperature of the SDC electrolyte layer using sintering additives.

Supplementary Materials: The following are available online at https:/ / www.mdpi.com/article/10 .3390/coatings11070805/s1, Figure S1: XRD patterns (log-scale) obtained for the electrolyte powders: as-prepared SDC powder (a), as-prepared BCZYYbO powder (b), BCZYYbO-CuO powder (sintered at $\left.1500^{\circ} \mathrm{C}\right)(\mathrm{c})$. Figure S2: Cross-section of the SDC electrolyte layer after final sintering at a temperature of $1500{ }^{\circ} \mathrm{C}$ for 5 hours on a porous anode substrate with a platinum sublayer: (a)-SEM image; (b)integral map of the elements' distribution; (c)-individual element maps. The platinum layer seen from the left side of the film is a Pt electrode sintered at $1100{ }^{\circ} \mathrm{C}$ serving for electrical measurements (not presented in this study).

Author Contributions: Conceptualization, methodology, investigation, formal analysis, writingoriginal draft preparation, E.K.; conceptualization, supervision, writing-review and editing, E.P.; investigation, L.E.; investigation, sample preparation, N.B. All authors have read and agreed to the published version of the manuscript.

Funding: The work was financially supported by the Russian Foundation for Basic Research, grant № 20-03-00151. Investigation of the kinetic properties of the suspensions was performed within the framework of the state assignment of IEP UB RAS (EPD thin-layer coatings, No. AAAA-A19119061090040-7). The study was in part carried out on the equipment of the Shared Access Center of "Composition of compounds" IHTE UB RAS and the Shared Access Centers of the IEP UB RAS and ISSC UB RAS.

Institutional Review Board Statement: Not applicable.

Informed Consent Statement: Not applicable.

Data Availability Statement: Not applicable.

Acknowledgments: The authors acknowledge the head of the Laboratory of chemistry of compounds of rare-earth elements (ISSC UB RAS), V.D. Zhuravlev and E.A. Filonova (Ural Federal University) for the materials supply and S.M. Pikalov (Institute of Metallurgy UB RAS) for the XRD characterization.

Conflicts of Interest: The authors declare no conflict of interest.

\section{References}

1. Su, H.; Hu, Y.H. Progress in low-temperature solid oxide fuel cells with hydrocarbon fuels. Chem. Eng. J. 2020, $402,126235$. [CrossRef]

2. Sreedhar, I.; Agarwal, B.; Goyal, P.; Singh, S.A. Recent advances in material and performance aspects of solid oxide fuel cells. J. Electroanal. Chem. 2019, 848, 113315. [CrossRef]

3. Tucker, M.C. Progress in metal-supported solid oxide fuel cells: A review. J. Power Sources 2010, 195, 4570-4582. [CrossRef]

4. Nguyen, X.V.; Chang, C.T.; Jung, G.B.; Chan, S.H.; Yeh, C.C.; Yu, J.W.; Lee, C.Y. Improvement on the design and fabrication of planar SOFCs with anode-supported cells based on modified button cells. Renew. Energy 2018, 129, 806-813. [CrossRef]

5. Ishihara, T.; Shimose, K.; Kudo, T.; Nishiguchi, H.; Akbay, T.; Takita, Y. Preparation of yttria-stabilized zirconia thin films on strontium-doped $\mathrm{LaMnO}_{3}$ cathode substrates via electrophoretic deposition for solid oxide fuel cells. J. Am. Ceram. Soc. 2000, 83, 1921-1927. [CrossRef]

6. Solov'ev, A.A.; Shipilova, A.V.; Ionov, I.; Kovalchuk, A.N.; Rabotkin, S.V.; Oskirko, V.O. Magnetron-sputtered YSZ and CGO electrolytes for SOFC. J. Electron. Mater. 2016, 45, 3921-3928. [CrossRef] 
7. Park, B.K.; Barnett, S.A. Boosting solid oxide fuel cell performance via electrolyte thickness reduction and cathode infiltration. J. Mater. Chem. A 2020, 8, 11626-11631. [CrossRef]

8. Prakash, B.S.; Pavitra, R.; Kumar, S.S.; Aruna, S.T. Electrolyte bi-layering strategy to improve the performance of an intermediate temperature solid oxide fuel cell: A review. J. Power Sources 2018, 381, 136-155. [CrossRef]

9. Hou, J.; Bi, L.; Qian, J.; Zhu, Z.; Zhang, J.; Liu, W. High performance ceria-bismuth bilayer electrolyte low temperature solid oxide fuel cells (LT-SOFCs) fabricated by combining co-pressing with drop-coating. J. Mater. Chem. A 2015, 3, 10219-10224. [CrossRef]

10. Hu, S.; Li, W.; Yao, M.; Li, T.; Liu, X. Electrophoretic deposition of gadolinium-doped ceria as a barrier layer on yttrium-stabilized zirconia electrolyte for solid oxide fuel cells. Fuel Cells 2017, 17, 869-874. [CrossRef]

11. Hui, R.; Wang, Z.; Kesler, O.; Rose, L.; Jankovic, J.; Yick, S.; Maric, R.; Ghosh, D. Thermal plasma spraying for SOFCs: Applications, potential advantages, and challenges. J. Power Sources 2007, 170, 308-323. [CrossRef]

12. Wen, J.; Song, C.; Liu, T.; Deng, Z.; Niu, S.; Zhang, Y.; Liu, L.; Liu, M. Fabrication of dense gadolinia-doped ceria coatings via very-low-pressure plasma spray and plasma spray-physical vapor deposition process. Coatings 2019, 9, 717. [CrossRef]

13. Oh, J.; Seo, G.; Kim, J.; Bae, S.; Park, J.W.; Hwang, J.H. Plasma-enhanced atomic layer deposition of zirconium oxide thin films and its application to solid oxide fuel cells. Coatings 2021, 11, 362. [CrossRef]

14. Smolyanskiy, E.A.; Linnik, S.A.; Ionov, I.V.; Shipilova, A.V.; Semenov, V.A.; Lauk, A.L.; Solovyev, A.A. Magnetron sputtered LSC thin films for solid oxide fuel cell application. J. Phys. Conf. Ser. 2018, 1115, 032080. [CrossRef]

15. Xu, M.; Yu, J.; Song, Y.; Ran, R.; Wang, W.; Shao, Z. Advances in ceramic thin films fabricated by pulsed laser deposition for intermediate-temperature solid oxide fuel cells. Energy Fuels 2020, 34, 10568-10582. [CrossRef]

16. Kim, Y.; Lee, S.; Cho, G.Y.; Yu, W.; Lee, Y.; Chang, I.; Baek, J.D.; Cha, S.W. Investigation of reducing in-plane resistance of nickel oxide-samaria-doped ceria anode in thin-film solid oxide fuel cells. Energies 2020, 13, 1989. [CrossRef]

17. Dunyushkina, L.A.; Khaliullina, A.S.; Kuimov, V.M.; Osinkin, D.A.; Antonov, B.D.; Pankratov, A.A. Influence of modification of chemical solution deposition on morphology and conductivity of $\mathrm{CaZr}_{0.9} \mathrm{Y}_{0.1} \mathrm{O}_{3-\delta}$ films. Solid State Ion. 2019, 329, 1-7. [CrossRef]

18. Kalinina, E.; Kolchugin, A.; Shubin, K.; Farlenkov, A.; Pikalova, E. Features of electrophoretic deposition of a Ba-containing thin-film proton-conducting electrolyte on a porous cathode substrate. Appl. Sci. 2020, 10, 6535. [CrossRef]

19. Kim, J.; Kim, J.; Yoon, K.J.; Son, J.W.; Lee, J.H.; Lee, J.H.; Lee, H.W.; Ji, H.I. Solid oxide fuel cells with zirconia/ceria bilayer electrolytes via roll calendering process. J. Alloys Compd. 2020, 846, 156318. [CrossRef]

20. Pikalova, E.Y.; Kalinina, E.G. Place of electrophoretic deposition among thin-film methods adapted to the solid oxide fuel cell technology: A short review. Int. J. Energy Prod. Manag. 2019, 4, 1-27. [CrossRef]

21. Sakka, Y.; Uchikoshi, T. Forming and microstructure control of ceramics by electrophoretic deposition (EPD). KONA Powder Part. J. 2010, 28, 74-90. [CrossRef]

22. Kalinina, E.G.; Pikalova, E.Y.; Menshikova, A.V.; Nikolaenko, I.V. Electrophoretic deposition of a self-stabilizing suspension based on a nanosized multi-component electrolyte powder prepared by the laser evaporation method. Solid State Ion. 2016, 288, 110-114. [CrossRef]

23. Das, D.; Bagchi, B.; Basu, R.N. Nanostructured zirconia thin film fabricated by electrophoretic deposition technique. J. Alloys Compd. 2017, 693, 1220-1230. [CrossRef]

24. Zehbe, R.; Mochales, C.; Radzik, D.; Müller, W.D.; Fleck, C. Electrophoretic deposition of multilayered (cubic and tetragonal stabilized) zirconia ceramics for adapted crack deflection. J. Eur. Ceram. Soc. 2016, 36, 357-364. [CrossRef]

25. Istomin, S.Y.; Antipov, E.V. Cathode materials based on perovskite-like transition metal oxides for intermediate temperature solid oxide fuel cells. Russ. Chem. Rev. 2013, 82, 686-700. [CrossRef]

26. Chelmehsara, M.E.; Mahmoudimehr, J. Techno-economic comparison of anode-supported, cathode-supported, and electrolytesupported SOFCs. Int. J. Hydrogen Energy 2018, 43, 15521-15530. [CrossRef]

27. Majhi, S.M.; Behura, S.K.; Bhattacharjee, S.; Singh, B.P.; Chongdar, T.K.; Gokhale, N.M.; Besra, L. Anode supported solid oxide fuel cells (SOFC) by electrophoretic deposition. Int. J. Hydrogen Energy 2011, 36, 14930-14935. [CrossRef]

28. Will, J.; Hruschka, M.K.M.; Gubler, L.; Gauckler, L.J. Electrophoretic deposition of zirconia on porous anodic substrates. J. Am. Ceram. Soc. 2004, 84, 328-332. [CrossRef]

29. Hosomi, T.; Matsuda, M.; Miyake, M. Electrophoretic deposition for fabrication of YSZ electrolyte film on non-conducting porous NiO-YSZ composite substrate for intermediate temperature SOFC. J. Eur. Ceram. Soc. 2007, 27, 173-178. [CrossRef]

30. Matsuda, M.; Hosomi, T.; Murata, K.; Fukui, T.; Miyake, M. Fabrication of bilayered YSZ/SDC electrolyte film by electrophoretic deposition for reduced-temperature operating anode-supported SOFC. J. Power Sources 2007, 165, 102-107. [CrossRef]

31. Chauoon, S.; Meepho, M.; Chuankrerkkul, N.; Chaianansutcharit, S.; Pornprasertsuk, R. Fabrication of yttria stabilized zirconia thin films on powder-injected anode substrates by electrophoretic deposition technique for solid oxide fuel cell application. Thin Solid Films 2018, 660, 741-748. [CrossRef]

32. Bozza, F.; Polini, R.; Traversa, E. High performance anode-supported intermediate temperature solid oxide fuel cells (IT-SOFCs) with $\mathrm{La}_{0.8} \mathrm{Sr}_{0.2} \mathrm{Ga}_{0.8} \mathrm{Mg}_{0.2} \mathrm{O}_{3-\delta}$ electrolyte films prepared by electrophoretic deposition. Electrochem. Commun. 2009, 11, 1680-1683. [CrossRef]

33. Kobayashi, K.; Takahashi, I.; Shiono, M.; Dokiya, M. Supported $\mathrm{Zr}(\mathrm{Sc}) \mathrm{O}_{2}$ SOFCs for reduced temperature prepared by electrophoretic deposition. Solid State Ion. 2002, 152-153, 591-596. [CrossRef]

34. Das, D.; Basu, R.N. Electrophoretic deposition of zirconia thin film on nonconducting substrate for solid oxide fuel cell application. J. Am. Ceram. Soc. 2014, 97, 3452-3457. [CrossRef] 
35. Suzuki, H.T.; Uchikoshi, T.; Kobayashi, K.; Suzuki, T.S.; Sugiyama, T.; Furuya, K.; Matsuda, M.; Sakka, Y.; Munakata, F. Fabrication of GDC/LSGM/GDC tri-layers on polypyrrole-coated NiO-YSZ by electrophoretic deposition for anode-supported SOFC. J. Ceram. Soc. Jpn. 2009, 117, 1246-1248. [CrossRef]

36. Zunic, M.; Chevallier, L.; Deganello, F.; D’Epifanio, A.; Licoccia, S.; Di Bartolomeo, E.; Traversa, E. Electrophoretic deposition of dense $\mathrm{BaCe}_{0.9} \mathrm{Y}_{0.1} \mathrm{O}_{3-x}$ electrolyte thick-films on Ni-based anodes for intermediate temperature solid oxide fuel cells. J. Power Sources 2009, 190, 417-422. [CrossRef]

37. Azarian Borojeni, I.; Raissi, B.; Maghsoudipour, A.; Kazemzad, M.; Talebi, T. Fabrication of solid oxide fuel cells (SOFCs) electrolytes by electrophoretic deposition (EPD) and optimizing the process. Key Eng. Mater. 2015, 654, 83-87. [CrossRef]

38. Meepho, M.; Wattanasiriwech, D.; Aungkavattana, P.; Wattanasiriwech, S. Reduction of electrode polarization in Anode-Supported Solid Oxide Fuel Cell. Energy Procedia 2015, 79, 272-277. [CrossRef]

39. Talebi, T.; Haji, M.; Raissi, B. Effect of sintering temperature on the microstructure, roughness and electrochemical impedance of electrophoretically deposited YSZ electrolyte for SOFCs. Int. J. Hydrogen Energy 2010, 35, 9420-9426. [CrossRef]

40. Talebi, T.; Raissi, B.; Haji, M.; Maghsoudipour, A. The role of electrical conductivity of substrate on the YSZ film formed by EPD for solid oxide fuel cell applications. Int. J. Hydrogen Energy 2010, 35, 9405-9410. [CrossRef]

41. Ishihara, T.; Sato, K.; Takita, Y. Electrophoretic deposition of $\mathrm{Y}_{2} \mathrm{O}_{3}$-Stabilized $\mathrm{ZrO}_{2}$ electrolyte films in solid oxide fuel cells. J. Am. Ceram. Soc. 1996, 79, 913-919. [CrossRef]

42. Oskouyi, O.E.; Shahmiri, M.; Maghsoudipour, A.; Hasheminiasari, M. Pulsed constant voltage electrophoretic deposition of YSZ electrolyte coating on conducting porous Ni-YSZ cermet for SOFCs applications. J. Alloys Compd. 2019, 785, 220-227. [CrossRef]

43. Jamil, Z.; Ruiz-Trejo, E.; Brandon, N.P. Nickel electrodeposition on silver for the development of solid oxide fuel cell anodes and catalytic membranes. J. Electrochem. Soc. 2017, 164, D210-D217. [CrossRef]

44. Bokov, A.A.; Boltachev, G.S.; Volkov, N.B.; Zayats, S.V.; Il'ina, A.M.; Nozdrin, A.A.; Paranin, S.N.; Olevskii, E.A. Uniaxial compaction of nanopowders on a magnetic-pulse press. Tech. Phys. 2013, 58, 1459-1468. [CrossRef]

45. Kalinina, E.G.; Pikalova, E.Y.; Kolchugin, A.A.; Pikalov, S.M.; Kaigorodov, A.S. Cyclic electrophoretic deposition of electrolyte thin-films on the porous cathode substrate utilizing stable suspensions of nanopowders. Solid State Ion. 2017, 302, 126-132. [CrossRef]

46. Uchikoshi, T.; Furumi, S.; Shirahata, N.; Suzuki, T.S.; Sakka, Y. Conductive polymer coating on nonconductive ceramic substrates for use in the electrophoretic deposition process. J. Am. Ceram. Soc. 2008, 91, 1674-1677. [CrossRef]

47. Nasani, N.; Shakel, Z.; Loureiro, F.J.A.; Panigrahi, B.B.; Kale, B.B.; Fagg, D.P. Exploring the impact of sintering additives on the densification and conductivity of $\mathrm{BaCe}_{0.3} \mathrm{Zr}_{0.55} \mathrm{Y}_{0.15} \mathrm{O}_{3-\delta}$ electrolyte for protonic ceramic fuel cells. J. Alloys Compd. 2021, 862, 158640. [CrossRef]

48. Kirillov, S.A. Surface area and pore volume of a system of particles as a function of their size and packing. Micropor. Mesopor. Mat. 2009, 122, 234-239. [CrossRef]

49. Pikalova, E.Y.; Kalinina, E.G. Electrophoretic deposition in the solid oxide fuel cell technology: Fundamentals and recent advances. Renew. Sustain. Energy Rev. 2019, 116, 109440. [CrossRef]

50. Besra, L.; Compson, C.; Liu, M. Electrophoretic deposition on non-conducting substrates: The case of YSZ film on NiO-YSZ composite substrates for solid oxide fuel cell application. J. Power Sources 2007, 173, 130-136. [CrossRef]

51. Solomentsev, Y.; Böhmer, M.; Anderson, J.L. Particle clustering and pattern formation during electrophoretic deposition: A hydrodynamic model. Langmuir 1997, 13, 6058. [CrossRef]

52. Ferrari, B.; Moreno, R. EPD kinetics: A review. J. Eur. Ceram. Soc. 2010, 30, 1069-1078. [CrossRef]

53. Heenan, T.M.M.; Vamvakeros, A.; Tan, C.; Finegan, D.P.; Daemi, S.R.; Jacques, S.D.M.; Beale, A.M.; Michiel, M.D.; Brett, D.J.L.; Shearing, P.R. The Detection of monoclinic zirconia and non-uniform 3D crystallographic strain in a Re-oxidized Ni-YSZ solid oxide fuel cell anode. Crystals 2020, 10, 941. [CrossRef]

54. Maher, R.C.; Shearing, P.R.; Brightman, E.; Brett, D.J.L.; Brandon, N.P.; Cohen, L.F. Reduction dynamics of doped ceria, nickel oxide, and cermet composites probed using in situ Raman spectroscopy. Adv. Sci. 2016, 3, 1500146. [CrossRef] 